University of California, Hastings College of the Law UC Hastings Scholarship Repository

Faculty Scholarship

2017

\title{
The Cold War and Comparative Law: A Reflection on the Politics of Intellectual Discipline
}

Ugo Mattei

UC Hastings College of the Law, matteiu@uchastings.edu

Alessandra Quarta

Follow this and additional works at: https://repository.uchastings.edu/faculty_scholarship

\section{Recommended Citation}

Ugo Mattei and Alessandra Quarta, The Cold War and Comparative Law: A Reflection on the Politics of Intellectual Discipline, 44 Am. J. Comp. L. 567 (2017).

Available at: https://repository.uchastings.edu/faculty_scholarship/1587

This Article is brought to you for free and open access by UC Hastings Scholarship Repository. It has been accepted for inclusion in Faculty Scholarship by an authorized administrator of UC Hastings Scholarship Repository. 


\section{The Cold War and Comparative Law: A Reflection on the Politics of Intellectual Discipline $\dagger$}

How much does the current state of comparative legal studies owe to Cold War political imperatives? What happened to our discipline once such imperatives declined in the aftermath of the bipolar world? Comparative lawyers have been completely naive about the impact of the Cold War on their own discipline both as it reached maturity in the 1950s and as it developed after the fall of the Berlin Wall until now. This consequence of the professional depoliticization of comparative law is especially troublesome since the Cold War has accompanied in its entirety the historical moment in which the common law tradition, especially in its U.S. epiphany, has been able to conquer global legal hegemony. Thus, the current disciplinary knowledge of comparative law, the very toolkit of our methodology, has developed in the context of the Cold War confrontation and has reached full global dominance in its aftermath. It is worth thinking about possible implications of this context on the professional project of legal comparativism if we wish to maintain an acceptable level of critical understanding of ourselves.

\section{BaCKGround}

An impressive debate has unfolded in many social sciences to assess the impact of Cold War mentality on the epistemology of the different disciplines. ${ }^{1}$ Scholars have agreed upon the necessity of reading the Cold War as something more than a discrete and relatively short historical period of confrontation between the United States and the Soviet Union. From a rich debate, it has emerged quite clearly that it is much more productive to see the Cold War as

* Alfred and Hanna Fromm Professor of International and Comparative Law, U.C. Hastings. Professor of Civil Law, Università di Torino. Fellow of Collegio Carlo Alberto and Academic Coordinator, International University College of Turin. Thanks to Dr. Alessandra Quarta (University of Turin) for her comments and her editorial assistance.

$\dagger$ http://dx.doi/org/10.1093/ajcl/avx024

1. See Universities and Empire: Money and Politics in the Social Sciences During the Cold War (Christopher Simpson ed., 1998) [hereinafter Universities AND EMPIRE]; The Cold War and the University: Toward an Intellectual History of the Postwar Years (Andre Shiffrin ed., 1997); Sonja M. Amadae, Rationalizing Capitalist Democracy: The Cold War Origins of Rational Choice Liberalism (2003). See also Hunter Heyck \& David Kaiser, Focus: New Perspectives on Science and the Cold War, 101 Isis 362 (2010).

(C) The Author [2017]. Published by Oxford University Press on behalf of the American Society of Comparative Law. All rights reserved. For permissions, please e-mail: journals.permissions@oup.com. 
a broader regime of knowledge production rather than as a historical time. $^{2}$

Academic lawyers have been completely absent from such a debate, and so important critical insights into their own role as producers of knowledge have been lost. This Article tries to fill this gap with respect to comparative legal studies. My research question is-How much does the current state of comparative legal studies owe to Cold War political imperatives? What happened to our discipline once such imperatives declined in the aftermath of the bipolar world? The question is important because the debate on the Cold War in social sciences has shown that after a quarter century since its official end, the regime of knowledge production determined by the Cold War still governs us from the grave, as Maitland used to say of the forms of action at common law. ${ }^{3}$

In this Article, I use the term "Cold War" in its broad meaning, in an attempt to understand transformations in the discipline of comparative law as the outcome of the confrontation between capitalism and its alternatives. ${ }^{4}$ Comparative lawyers have been completely naive about the impact of the Cold War on their own discipline both as it reached maturity in the 1950s and as it developed after the fall of the Berlin Wall until now. ${ }^{5}$ This consequence of the professional depoliticization of comparative law is especially troublesome, since the Cold War has accompanied in its entirety the historical moment in which the common law tradition, especially in its U.S. epiphany, has been able to conquer global legal hegemony. ${ }^{6}$ Thus, the current disciplinary knowledge of comparative law, the very toolkit of our methodology, has developed in the context of the Cold War confrontation and has reached full global dominance in its aftermath. It is worth thinking about possible implications of this context for the professional project of legal comparativism ${ }^{7}$ if we wish to maintain an acceptable level of critical self-understanding.

The American century in law started by contrasting itself with the poor performance of the continental civil law in facing the rise of the fascist state in Italy, Germany, and Japan (not to mention

2. See Bruce Cumings, Boundary Displacement: Area Studies and International Studies During and After the Cold War, in Universities AND EMPIRE, supra note 1, at 159.

3. See Frederic W. Maitland, The Forms of Action at Common Law: A Course of LeCTURES (Alfred Henry Chaytor \& William Joseph Whittaker eds., 1936).

4. In a sense, this Article could be a chapter in John Quigley, Soviet Legal InNOVATION AND THE LAW OF THE WeSTERN WORLD (2012).

5. A very recent interesting development has occurred in the Italian academic scene where two leading comparatists, independently from each other, have published books on the geopolitics of comparative law. See MaUro Bussani, IL DiritTo dell' Occidente: Geopolitical delle Regole globali (2010); Piergiuseppe Monateri, Geopolitica del DiRitTo: Genesi, governo e Dissoluzione DeI CORPI Politici (2013).

6. See Ugo Mattei, Why the Wind Changed: Intellectual Leadership in Western Law, 42 Ам. J. Comp. L. 195 (1994).

7. See Magali Sarfatti Larson, The Rise of Professionalism (1977). 
Vichy France). It went on to differentiate itself from the law in the Soviet Union and more broadly in the socialist world until the official end of the Cold War. The American century has reached the present times in which the constructed "evil" appears to be the Islamic legal tradition diffused through "rogue states" or "failed states," other global competitors, such as China, consistently deemed to lack the rule of law. ${ }^{9}$ It is very unlikely that this attitude, almost unanimous among lawyers, would leave the comparative law community untouched, in spite of its self-image as the only worldly approach to legal studies in the United States. ${ }^{10}$ In the United States, the dominant legal culture from the early twentieth century has reduced legal cosmopolitanism into the Wilsonian missionary spirit of teaching others the right way of doing things rather than engaging with unbiased understanding of legal "otherness."11 Even if lawyers are historically marginalized in American campus life, and comparatists the marginalized among lawyers, their struggle to claim a seat among "social scientists" has been itself a product of the Cold War spirit. Even before rational choice theory, the brainchild of the Rand Corporation, took over the American legal discourse by means of the "law and economics"12 movement, the realist triumph in the interwar years is difficult to understand outside of the confrontation with communist Russia and its attack on the bourgeois rule of law. The Cold War moreover triggered the creation of the International and Area Studies programs especially at Columbia, Harvard, and the Massachusetts Institute of Technology (MIT), with a massive injection of military money ${ }_{13}^{13}$ either directly or through like-minded intermediary foundations and corporations. ${ }^{14}$

Within a new strategy to deploy a politically disciplined interdisciplinary work needed for useful intelligence of the world, the few academic lawyers who were engaged in international and comparative work were natural candidates to participate in such interdisciplinary research projects. Cold War money promoted the development of new alliances in social sciences to "progress" from the classic, early twentieth-century division into economics, sociology, political science, and history, whose success in depoliticizing social

8. See Pinar Bilgin \& Adam David Morton, Historicizing Representations of "Failed States": Beyond the Cold War Annexation of the Social Sciences?, 23 THIRD WORLD Q. 55 (2002).

9. See Ugo Mattei \& Laura Nader, Plunder: When the Rule of Law is Illegal 67ff. (2008).

10. See Günter Frankenberg, Critical Comparisons: Rethinking Comparative Law, 26 Harv. INT'L L.J. 411, 416 (1985).

11. See Jedidiah Kroncke, The Futility of Law afnd Development: China and the Dangers of Exporting American Law (2015).

12. See Amadae, supra note 1. See also David C. Engerman, Social Science in the Cold War, 101 Isis 393 (2010).

13. See Stunart W. Leslie, The Cold War and American Science: The MilitaryIndustrial ACADEMIC CompleX AT MIT AND STANFORd (1993).

14. See Cumings, supra note 2. 
theory and shielding it from deep critique was an acquis..$^{15}$ Thus, in the early 1950 s, many professional academic associations were created in the United States in an unprecedented effort of professionalization of disciplinary knowledge to create enduring professional hierarchies. ${ }^{16}$ The birth of the American Society of Comparative Law (ASCL) dates to 1951. Since its creation, the ASCL has become the dominant national group at the International Academy of Comparative Law founded by the international organization of comparatists in $1924^{17}$ at least in part as a response to Soviet legal innovation.

The scant attention paid by the comparative legal community to its own historical contextualization might seem at first to be at odds with a number of its established methodological claims, such as the claim that "comparison involves history" or its self-image as either directly a social science or at least as indispensable to any serious effort to approach law as a social science. However, someone becoming acquainted with the literature on the impact of the Cold War on social sciences will see no contradiction. The lack of attention on the part of comparative lawyers to the impact of the Cold War (and its money) on the methodology and claims of their discipline is a direct consequence of the broader phenomenon of "depoliticization" of the legal discourse. ${ }^{18}$ This phenomenon, captured by the dominant metaphor of the lawyer as a "social engineer" inaugurated in the age of legal realism in the aftermath of World War I, attained global dominance by the fall of the Berlin Wall. ${ }^{19}$ Comparative law in the early phase of the Cold War eagerly participated in the project, which it believed to be a methodological progress, but which in fact was just a response to research agendas defined in higher political places to establish what has become the dominant regime of knowledge. Particularly successful in the containment of the political critique in the discipline of comparative law has been the construction of history as a science in its own terms, so that other branches of social sciences not only divided human activity into naturalized non-communicating domains (the political, the economic, and the social) but focused on the present. Consequently, the history used (when at all) (1976).

15. The classic discussion remains Roberto Unger, Knowledge and Politics

16. See Cumings, supra note 2. See also Daniel Vukovich, Postcolonialism, Globalization, and the "Asia Question," in The Oxford Handbook of Postcolonial STudies 587, 589 (Graham Huggan ed., 2013).

17. See David S. Clark, Development of Comparative Law in the United States, in The Oxford Handbook of Comparative Law 176 (Mathais Reimann \& Reinhard Zimmermann eds., 2006).

18. See Mark Kelman, A Guide to Critical Legal Studies (1987). See also Duncan Kennedy, Political Ideology and Comparative Law, in The CAmbridge Companion to Comparative Law 35 (Mauro Bussani \& Ugo Mattei eds., 2012).

19. See Ugo Mattei, The Rise and Fall of Law and Economics: An Essay for Judge Guido Calabresi, 64 MD. L. REv. 220 (2005). 
in the social sciences is itself disciplined and incapable of producing a political critique of the present.

Comparative law did not escape this fate. ${ }^{20}$ The historical approach deployed is itself disciplined within an idea of legal history, a formalistic separation of the past from the present that makes it very hard to learn from earlier mistakes. The lack of a historical understanding of one's own roots easily leads to an imaginary self-image, with the almost unavoidable consequence of developing hubris, or what one scholar has brilliantly described as a disciplinary Cinderella complex..$^{21}$

In the present Article, I will deal with the history of comparative law in a very different way. To begin with, I shall not disentangle it from academic law in general and will see its historical unfolding not as an autonomous discipline ${ }^{22}$ but as a part (quite small indeed) of a broader phenomenon of knowledge production in which the West incrementally shifted away from any comparative project and actually developed sophisticated techniques of self-congratulation. In so doing, I consider the various attempts at making comparative law something like a neutral science, as a historically situated ideological contribution in the production of disciplined knowledge, and I try to approach the comparative study of law within the pattern of global legal hegemony where it is the American version of comparative law that matters the most globally. ${ }^{23}$ This is not a paper about how to compare the law. It is rather a reflection on the political, historical, and social circumstances that make us compare the way we do.

Because the Cold War was about capitalism versus socialism, the historical period that I consider extends beyond the actual Cold War as a time period of roughly forty years from the immediate aftermath of the Allied victory against Nazi Germany. ${ }^{24}$ In my understanding, the Cold War started immediately after the October Revolution in 1917 conquered American public opinion during the Red Scares of the $1920 \mathrm{~s}$, and never relented as a clash between two incompatible visions of human organization, in spite of the common effort against Nazi Germany. The atomic bombing of Hiroshima in this perspective is much easier to explain as a Cold War attempt to contain the USSR in Asia rather than as a final strike against what was left of the Axis Alliance (Germany-Japan). ${ }^{25}$

20. See James Gordley, Comparative Law and Legal History, in The Oxford HaNDBook of Comparative LaW, supra note 17, at 754.

21. Frankenberg, supra note 10.

22. See Mathias Reimann, The End of Comparative Law as an Autonomous Discipline, 11 Tul. Eur. \& CIv. L.F. 49 (1996).

23. See Ugo Mattei, Some Realism About Comparativism: Comparative Law Teaching in the Hegemonic Jurisdiction, 50 Aм. J. Comp. L. 87 (Supp. 2002).

24. For essential historical background, see Lynn Etheridge Davis, The Cold War Begins: Soviet-American Conflict over EAST EuRope (1974).

25. See Jacques R. Pawels, The Myth of the Good War: America in the Second WORLD WAR (2002). 
I will thus consider the dialectic between Western and socialist law as it affected comparative law throughout most of the twentieth century.

One more point of clarification: in this Article, I am interested in comparative law as a collective enterprise of a loosely organized academic community. I am not interested in tracing the most original ideas or the earliest individual scholar who contributed such ideas to the community. Comparative law in my understanding is itself a "derivative" scholarly discipline, and many of the ideas and tools that we develop in our line of business find their genealogy elsewhere. So, for example, much of the work on functionalism-structuralism pioneered in the 1920s and 1930s by the German scholar Ernst Rabel—work which he applied to comparative law in the 1950s and 1960s when he immigrated to the United States-was itself probably derivative of the work by Bronisław Malinowski and other social anthropologists. ${ }^{26}$ To me what matters for the purposes of this Article is that Rabel's work became mainstream in comparative law during the Cold War. Zweigert and Koetz applied it in their introduction to comparative law (in the first edition in 1969), ${ }^{27}$ Schlesinger deployed it at the Cornell seminars (1960-1966), and Sacco, through Gorla, stretched it to a sort of general theory (entirely limited to private law) that has dominated Italian academia. ${ }^{28}$

I find it difficult to believe the dominant narrative, which turns the private law bias of our modern discipline into a historical tradition dating back to Roman law. I claim that this bias, around which comparatists have developed the very notion of the Western legal tradition as well as most of the dominant taxonomies, finds a better explanation as an effort to defend capitalist law against the thick intellectual critique of Eugeny Pashukanis who, in 1924, unveiled the class nature of legal universalism. ${ }^{29}$

I also consider relevant the professional organization of the discipline and its timing. Quite significantly, the International Academy of Comparative Law was founded in 1924, in the midst of legal innovations promoted by Lenin through the New Economic Policy (NEP). ${ }^{30}$ The Faculté Internationale de Droit Comparé (FIDC) was

26. See Laura Nader, Who's Comparative Law? A Global Perspective, in Comparative LaW and Anthropology (James Nafziger ed., 2017).

27. Indeed Konrad Zweigert, Methodologie du droit comparé, in Melanges offerts A JACQUES MAURY 579 (1960) had already fully developed the methodological functionalist groundwork of the introduction.

28. See Elisabetta Grande, Development of Comparative Law in Italy, in The Oxford Handbook of Comparative Law 107 (Mathias Reimann \& Reinhard Zimmermann eds., 2010). See the methodological discussion in Rodolfo Sacco, Legal Formants: A Dynamic Approach to Comparative Law, 39 Aм. J. Comp. L. 1 (1991) (referring to Gino GoRla, Il Contratto (1955)).

29. See Evgeny Pashukanis, The General Theory of Law And Marxism (1924).

30. The International Institute for the Unification of Private Law (UNIDROIT), another early organization where comparatists were active, was established in 1926 as an organ of the League of Nations, an organization joined by the Soviet Union in 1934 only to be expelled (illegally) in 1939 . 
established in 1961 in an organizational effort that has instituted the dominant taxonomies much more solidly than their theoretical robustness, as we will see. I borrow from John Quigley the mirror image explanation of Soviet legal innovation as a trigger of Western legal change. ${ }^{31}$

In sum, contrary to the dominant tradition, I place the beginning of a scientific claim of comparative law at a time when the very notion of universal science was being disputed at the Soviet Academy of Science. In the heat of the confrontation between capitalism and its adversary, nothing remained shielded from the total critique and triggered a call to arms in the restructuring of the, until then undisputed, scientific knowledge. ${ }^{32}$ Comparative lawyers, more or less consciously have framed their own niche of disciplined learning in reply to that call.

\section{The Disciplined NarRative}

The accepted disciplinary wisdom of comparatists is that comparative law came of age as an autonomous discipline in the 1950s out of an internal scientific evolution. The dominant narrative is that, before the mid-twentieth century, and before (and after) its conventional date of birth (the 1900 Paris Congress of the Sociéte de Législation Comparée), comparative law was an amateurish practice of a limited number of erudite scholars whose methodological approach was quite primitive. ${ }^{33}$

Lawyers engaging in the study of foreign law from the second half of the nineteenth to the early twentieth century would take the law of the different countries, so to speak, at face value. ${ }^{34}$ They would learn something about a foreign legal system by reading books written by local scholars. In the absence of any critical method, the self-perception of such domestic scholars became the accepted canon. The birth of the most enduring stereotypes of comparative law dates back to this early phase of "contrastive" comparative law when a few European scholars were interested in comparative legislation in

31. See Quigley, supra note 4. The foundation of the International Labour Organisation (ILO) is an especially interesting reaction of capitalist powers to the early socialist labor emancipation through law.

32. See Slava Gerovitch, Writing History in the Present Tense: Cold War-Era Discursive Strategies of Soviet Historians of Science and Technology, in UNIVERSITIES AND Empire, supra note 1, at 189, 192 (citing Boris Hessen, The Social and Economic Roots of Newton's "Principia," in Science AT the Crossroads 182 (Nicholai Bukharin et al. eds., 1971) (1931)).

33. See Mathias Reimann, Beyond National Systems: A Comparative Law for the International Age, 75 Tul. L. Rev. 1103 (2000-2001). See also Rethinking the Masters of Comparative LaW (Annelise Riles ed., 2001).

34. On Wigmore's naiveté, see Annelise Riles, Wigmore's Treasure Box: Comparative Law in the Era of Information, 40 HARV. INT'L L.J. 221 (1999). 
order to overcome the formidable intellectual and linguistic barriers that European statehood had produced among the legal systems. ${ }^{35}$

From the second half of the nineteenth century, anyone wishing to familiarize themselves with a matter of French law would most likely be struck by the emphasis it places on the Civil Code, and more generally on statutes, as the dominant, almost unique source of law that had survived the French Revolution. Despite François Geny, the common wisdom among French lawyers was that "case law" was all but a swear word in French jurisprudence. During the same period, a student of the sources of English law would find himself at the very zenith of the doctrine of stare decisis. The Judicature Acts (1873) had just created the hierarchical structure necessary for stare decisis to become meaningful. Indeed, the practice of following precedents, both horizontally and vertically, transformed itself into a strict legal duty from the beginning of the twentieth century to the Practice Statement of $1966 .{ }^{36}$ At Oxbridge, Maitland, Pollock, and other Victorian academic lawyers and legal historians would exaggerate the insularity and uniqueness of English law, and their vision would become the canon among the early comparatists. In the same period, someone inclined to study German law would find a relentless self-congratulatory rhetoric of then globally dominant German academic lawyers, whose masterpiece, the general part of the German Civil Code was still to come. ${ }^{37}$

This was the scenario that the early Italian comparative lawyer and politician Emerico Amari would find when writing his (naive) 1859 book on comparative legislation. Taking the municipal professional descriptions at face value, comparatists would conclude that the civil law is a tradition of codified law, with no role for case law (France) and a large influence of professors (Germany). They contrasted it sharply with the casuistry of the common law, a tradition where case law is the dominant source of law because of the principle of stare decisis that made it binding. ${ }^{38}$

The conventional wisdom of our discipline signaled an abrupt change in the two central decades of the last century, witnessed among other things by the publication of a few classics, very different among each other, but sharing a new "professional" quality. Rudolf B. Schlesinger in the United States (1950), ${ }^{39}$ René David in France (1950), ${ }^{40}$ Frederick Henry Lawson in England (1953), ${ }^{41}$ Gino Gorla

35. See Rudolf B. Schlesinger, The Past and Future of Comparative Law, 43 Aм. J. Comp. L. 477 (1995).

36. See John H. Baker, An Introduction into English Legal History (2005).

37. John P. Dawson, The Oracles of the LaW (1968).

38. See Leontin-Jean Constantinesco, Traité de droit comparé (1972).

39. Rudolf B. Schlesinger, Comparative Law: Cases, Texts, Materials (1950).

40. René David, Les grands systèmes de droit contemporains (R. David John \& E.C. Brierley trans., 1985) (1964).

41. F.H. Lawson, A Common Lawyer Looks at the Civil Law (1953). 
in Italy (1955), ${ }^{42}$ and Konrad Zweigert and Hein Koetz in Germany $(1969)^{43}$ are widely accredited as being the movers and shakers of this change. These great masters were uniquely equipped to go beyond the faithful belief of what domestic lawyers of a different country would say about their own legal systems. These intellectual giants were professionally capable of verifying the truth of a foreign statement about the law, either because, like Schlesinger, they were fully trained in one civil law and one common law jurisdiction; ${ }^{44}$ or because, like Gorla and David, they spent a significant amount of time studying and teaching in remote contexts (Egypt and Ethiopia, respectively); or because of a unique degree of familiarity with Roman law (such as Lawson in 1953, and Alan Watson in 1974), they were equipped, as nobody before them, to check the ideological self-perception of municipal lawyers. ${ }^{45}$ Thus, for reasons that are, so to speak, internal to the profession, comparative law was able to go beyond the mere juxtaposition of black letter law. The quality and culture of the legal professionals engaging with it explains how the discipline reached a much more advanced stage of intellectual development. ${ }^{46}$

In a broader but still legal context, outside of the narrow discipline of comparative law, the professional explanation of the "coming of age" of comparative law seems even more solid. Legal realism was now dominant in the United States, ${ }^{47}$ and the United States was globally hegemonic. ${ }^{48}$ Black letter analysis, discredited in the United States, became an object of increasing critique in Europe among the most advanced schools of thought. ${ }^{49}$ Since World War I, it had become increasingly clear that the traditional conceptualistic approach of legal formalism led to absurd results even in a core area of private law, such as property and contract, shaken as they were by the war effort. ${ }^{50}$ Legal scholars were following domestic legal changes to

42. Gino GoRla, Il CONTRATto (1954).

43. K. Zweigert \& H. Koetz, An Introduction of Comparative Law (Tony Weir trans., 2d ed. 1988).

44. See Rudolf B. Schlesinger, Memories (Ugo Mattei \& Andrea Pradi eds., 2000).

45. The dominant scientific narrative in comparative law has been somewhat formalized by Rodolfo Sacco, Legal Formants: A Dynamic Approach to Comparative Law, 39 Aм. J. Comp. L. 1 (1991). For a discussion, see Ugo Mattei, The Comparative Jurisprudence of Schlesinger and Sacco: A Study in Legal Influence, in RETHINKING the Masters of Comparative Law, supra note 33, at 238.

46. For additional information and some materials for a history of the discipline, see Rethinking the Masters of Comparative Law, supra note 33.

47. See Gary Minda, Postmodern Legal Movements: Law and Jurisprudence at Century's End (1995).

48. See Ugo Mattei, A Theory of Imperial Law: A Study on U.S. Hegemony and the Latin Resistance, 10 Ind. J. Global Legal Stud. 383 (2003).

49. See Karl Renner, The Institutions of Private Law and Their Social Functions (1949); Leon Duguit, Law in the Modern State (1919); Ludwig Raiser, Die Aufgabe des PRIVATReChts (1977). See generally Anna di Robilant, Property: A Bundle of Sticks or a Tree?, 66 VAND. L. REV. 869 (2014).

50. Especially in property law, the idea of the voluntary and despotic dominium could not survive the reality of an increasingly interventionist state. In the United States, Hohfeld was looking into the variety of relationships to exit from the conundrum. See Wesley N. Hohfeld, Fundamental Legal Concepts as Applied in Judicial Reasoning, 23 YALE L.J. 16 (1913). 
attune their analytical tools to reality. Legal realism attracted nonlawyers to U.S. law schools that were helping in a scholarly effort to make law accepted among the social sciences. ${ }^{51}$ The different "mirror images" of law as reflective of the social reality would serve the purpose of making lawyers accepted among social scientists and social engineers. ${ }^{52}$

Thus, there is more to the narrow explanation of the coming to age of comparative law as an autonomous methodological improvement in the discipline due to the exceptional quality of some of its professional leaders. A broader, still professional, explanation has to do with the change in the intellectual leadership in Western law that took place in the immediate aftermath of World War II ${ }^{53}$ To be sure, American hegemony in jurisprudence contributed to comparative law in a significant way through a healthy injection of legal realism. It is sufficient to think about Dean Roscoe Pound, whose work ridiculed the so-called "mechanical jurisprudence" of the French Jacobean rhetoric; ${ }^{44}$ or Karl Llewellyn, whose work on case law in Germany, only recently published in English, shows an unprecedented degree of awareness and comparative sophistication. ${ }^{55}$ In short, American legal culture contributed to the fundamental distinction between law in the books and law in action, and the consequent functionalist shift, which is the closest thing we have to "a canon" in contemporary comparative law. ${ }^{56}$ This broader professional explanation contributes to the idea (criticized only very recently) that comparative law, like other social sciences, is a nonpolitical, neutral exercise.

\section{A Broader Approach}

In this Article, I look for a different explanation of the coming to age of comparative law and its current paradoxical decline ${ }^{57}$ Despite my skepticism about the narratives of improvement, I do not wish to dismiss the conventional wisdom. There is some truth in assuming an incremental process of sociological transformation of a relatively new academic discipline that, practiced more professionally, displays a methodological "improvement" from the lack of awareness

51. See Grant Gilmore, The Ages of American Law (1977).

52. See Wolfgang Friedman, The Changing Structure of International Law (1964); the "mirror image" explanation of legal change by Friedman triggered the critique of Alan Watson, Society and Legal Change (1977).

53. See Duncan Kennedy, Three Globalizations of Law and Legal Thought: 18502000 , in The New Law and Economic Development 19, 25-71 (David M. Trubek \& Alvaro Santos eds., 2006); Mattei, supra note 6.

54. See Roscoe Pound, Mechanical Jurisprudence, 8 Colum. L. Rev. 605 (1908).

55. Karl N. Llewellyn, The Case Law System in America (Michael Ansaldi trans., Univ. Chicago Press 1989).

56. See Reimann, supra note 33.

57. Ugo Mattei, An Opportunity Not to Be Missed: The Future of Comparative Law in The United States, 46 Ам. J. Cомp. L. 709 (1998). 
of the early législation comparée to the intellectual sophistication of the functionalist methodology as deployed by Schlesinger. The conventional narrative is internal to the discipline, and-while perhaps ungenerously dismissive of the quite impressive degree of methodological awareness of some of its early students (like Montesquieu if compared to his contemporaries $)^{58}$ - it is certainly helpful. Even expanding it to include in the picture American legal hegemony, and the hegemony of legal realism within it, we are still within a professionalized explanation which assumes the progress of science to be ultimately independent from political needs.

I wish, however, to supplement this vision with an external explanation of both the content and timing of the coming of age of comparative law. My explanation calls attention to the impact of the Soviet Revolution and the Cold War on the Western legal community. I submit that the radicalism of the Soviet critique to the bourgeois legality has not only led to much innovation in the substantive laws of Western countries, but also impacted comparative law. The young discipline received strong incentives to develop new, less formalistic methodologies in order to participate in the overall political project of reacting to the intellectually powerful communist challenge to Western legality. At least since the Wilsonian period, the approach of the U.S. legal community, and more broadly of American public discourse, began its notorious missionary spirit to export the rule of law. Earlier moments of genuine interest in the law of other people, still very vibrant in, say, Benjamin Franklin, were discontinued as the comparative project incrementally transformed itself in an effort to teach the "others" the superiority of American law. ${ }^{59}$ The political climate of the Cold War exacerbated this tendency, but at the same time accrued the effort to know one's enemy (and one's friends). ${ }^{60}$

Here the political explanation must be qualified. On the one hand, one could argue that, as a social discipline, comparative law changed so as to reflect the different social and legal conditions, such as the birth of the Soviet Union in 1922 or that of the People's Republic of China in 1949, which it has autonomously identified as relevant. This explanation would still consider the setting of the research agenda to be within the province of the scholars. Better scholars are going to pose more interesting research questions. ${ }^{61}$ My suggestion is of a different nature. ${ }^{62}$ I suggest that comparatists have been part of an agenda set elsewhere in political and

58. See, e.g., Peter Stein, Legal Evolution: The Story of an Idea (2009).

59. See the excellent study in Jedidiah Kroncke, Law and Development as AntiComparative Law, 45 VAND. J. TRANSNAT'L L. 477 (2012).

60. See Universities AND Empire, supra note 1.

61. See Karl Popper, The Logic of Scientific Discovery (1934).

62. See Teemu Ruskola, Legal Orientalism: China, the United States, and Modern Law (2013). See also Popper, supra note 61. On the Cambridge Companion to Comparative Law, see KRONCKE, supra note 11. 
economic networks (e.g., philanthropist foundations, the Department of Defense, the Office of Strategic Services) participating in the effort of containing the spread of socialism, which at the time was both a politically and a jurisprudentially credible alternative to capitalism. ${ }^{63}$ Thus, I use the idea of a "Cold War" attitude in the profession without any meaning whatsoever of a shared political agenda among professional comparatists. Konrad Zweigert, for instance, was actively involved in politics in the early 1960s with the Social Democratic Party, which at the time was still officially Marxist. Nevertheless, professional comparatists could not remain immune to the setting of an internationalist agenda of containment, when such an agenda came endowed with tremendous money and political-academic support. Ford Foundation money, for example, enabled projects in "law and development" in which American masters of comparative law, such as John Merryman, were among the "law and development" leaders. ${ }^{64}$ The Ford Foundation also funded, even more important in this context, the Cornell Project on the "common core of legal systems" that brought to Cornell an entire generation of world comparatists (including Gino Gorla) to study with Schlesinger. Legal Sovietology could not have even existed if the travels and organizational efforts of John Hazard and Harold Berman had not been lavishly funded by Rockefeller Foundation money at the Russian institutes at Columbia and Harvard. The Carnegie Corporation, too, was active in this enterprise and has routinely funded for many years the Cornell Common Core Project. ${ }^{65}$ Scholarly enterprises needed political support, and the line separating academic scholarship from intelligence was very thin (when existing at all) during the Cold War confrontation. ${ }^{66}$

The Cold War indeed explains the bipartisan political climate diffused in the United States after the "red scares" of the 1920s well beyond the excesses of McCarthyism of the 1950s. The construction of critique as "un-American" and of opposition as disloyalty does not require the excesses of the Senate Committee or of the recurrent Stalinist purges to affect scholarship. Selfcensorship, for fear, opportunism, or even just lack of critical

63. China was not a credible legal alternative. It is no surprise that comparatists devoted very scant attention to this experience until it became itself a credible threat after 1978. China remained relegated in the pariah status of the "other" conceptions.

64. John H. Merryman, Comparative Law and Social Change: On the Origins, Style, Decline and Revival of the Law and Development Movement, 25 Aм. J. Comp. L. 457 (1997). On the origins and might of the Ford Foundation, see Francis X. Sutton, The Ford Foundation: The Early Years, 116 DaEdalus 41 (1987).

65. Schlesinger acknowledged this funding in 1 Formation of Contracts: A STUdy of the Common Core of Legal Systems (Rudolf B. Schlesinger ed., 1968) [hereinafter Formation of Contracts].

66. See Sigmund Diamond, Compromised Campus: The Collaboration of Universities With the INTELLIGENCE CoMMUNITY, 1945-1955 (1992). 
spirit, is a widely diffused attitude in academia, yesterday as today, on this side or the other of the walls. The Cold War phantom $^{67}$ has triggered a massive investment in the so-called annexation of social sciences and in the creation of international and area studies programs in the United States. My claim is that comparative law came of age the way it did, not only "within" the ideological effort of containment, but more precisely "because of" this capitalist effort to protect itself.

With the torch of the Western legal hegemony in the United States, Germany traumatized by the partition (though the construction of the Berlin Wall began only in 1961), and the success of the Maoist revolution in China, comparative law scholars were finding it hard to share their capitalist colleagues' old positivistic vision of the law. Neither legal realism, nor the legal process-it is worth stating clearly-abandoned the positivistic stance. In the dominant domestic approach, law was still the product of state sovereignty; to the community of those engaged in comparative study, such a reductionist vision was an obstacle to developing meaningful general taxonomies aimed at managing the increasing complexity of a worldwide legal scenario. Comparative lawyers stimulated by a shared research agenda with social scientists, were at the same time busy looking into a strategy aimed at delegitimizing the communist legal order despite its positivistic legitimacy, and looking into non-positivistic factors of unity rather than of division within the capitalist block.

To do so, they deployed a double-standard strategy. On the one hand, it was necessary to both maintain and qualify the traditional distinction between the common law and civil law. This was still the main subject matter of the relatively new discipline grounded in the earlier "contrastive" approach of the législation comparée. ${ }^{68}$ On the other hand, this classic opposition could not be grounded in political options, which nevertheless were the unifying element of the "socialist law family." Thus a quite remarkable degree of ambiguity as to the choice between "contrastive" rather than "integrative" methods. The early work on the "Western concept of law," which generated Geoffrey Sawers's long essay in the International Encyclopedia of Comparative Law ${ }^{69}$ (excerpts of which made it

67. See Laura Nader, The Phantom Factor: Impact of the Cold War on Anthropology, in The Cold War AND the University 107 (Noam Chomsky et al. eds., 1997). I use in this Article the idea of "phantom" as the construction of a Cold War mentalité by the ideological apparatuses (in the sense of Althusser) of the different states involved.

68. See Schlesinger, supra note 35.

69. See Geoffrey Sawer, The Western Conception of Law, in 2 International Encyclopedia of Comparative LaW 14 (René David ed., 1975) (completed by the author in July 1973). A more recent discussion of the Western legal tradition can be found in Antonio Gambaro, Western Legal Tradition, in 3 The New Palgrave Dictionary of ECONOMics AND the LaW 687 (Peter Newman ed., 1998). 
into various casebooks), was necessary to inaugurate a politically unavoidable claim of unity of capitalist countries. ${ }^{70}$

The whole Encyclopedia exudes the effects of Cold War equilibria. To begin, Victor Knapp-a leading Czechoslovakian jurist and professor in Prague for many years active in teaching the socialist legal family at the FIDC-received the honor and the responsibility of editing the first, and perhaps most politically delicate, volume, six years in the making when it appeared in 1972. The introduction to the work, which was on Knapp's desk during the Prague Spring of 1968, acknowledges the political contentiousness of the enterprise. While falling short of claiming political neutrality, the famous jurist defends certain standards of scientific honesty capable of defeating political arbitrariness. He claims political responsibility for any final choice in contentious matters (mostly the recognition of the statehood of some, rather than other, contested Cold War entities). The entry on the USSR was collectively authored by the Institute of State and Law of the Academy of Sciences of the USSR, a clear sign of political distension brokered by the authority of Knapp. In Volume II on the "Different Conceptions of Law," whose long introduction was completed in January 1972, René David displays an "integrative spirit"11 by acknowledging, alongside the usual claim of the possibility and desirability of scientific comparison, that Western legalism could learn from different visions, where law has a less prominent role. While it is difficult to interpret whether David had in mind socialist legality, it is a fact that he gave up his famous classification. He determined that the common law and civil law were to stay together within a Western conception of law, located immediately before the chapter on the "Socialist Conception of Law," completed in January 1970 by the leading Hungarian comparatist Imre Szabo. ${ }^{72}$

However, this integrative approach could not be carried to its logical conclusion of suggesting in the Marxian tradition, that all that mattered was the contrast between bourgeois and socialist structures of production. ${ }^{73}$ While the early clear-cut opposition between civil law and common law was discussed anew in light of a more integrative platform, it remained a stronghold of comparative law shared by all possible classifications. David, Zweigert and Koetz, Costantinesco, and Schlesinger all maintained the opposition at the

70. The International Encyclopedia of Comparative Law, under the auspices of the United Nations Educational, Scientific and Cultural Organization (UNESCO), can be considered the most ambitious attempt generated in the scientific maturity of the discipline. The project, conceived in the early to mid-1960s, generated its first published result in 1 National Reports (Victor Knapp ed., 1972). See Adolf Sprudzs, The International Encyclopedia of Comparative Law: A Bibliographical Status Report, 28 Ам. J. Comp. L. 93 (1980).

71. R. Schlesinger, The Past and the Future of Comparative Law, 43 Aм. J. Comp. L. 477 (1995).

72. Imre Szabo, The Socialist Conception of Law, in InTERNATIONAL EnCYCLOPEDIA of Comparative Law, supra note 69, at 49.

73. See Hugh Collins, Marxism and Law (1984). 
core of their taxonomies, but at the same time reserved an undisputable hard "contrastive" approach in making socialist law the "third family" of legal systems. ${ }^{74}$ Here the classifying principle was political, but not to the point of acknowledging the very "incomparability" between communist law and bourgeois law.

This effort to produce a self-congratulatory capitalist identity, going beyond legal positivism, and the rebuttal to the claim of incomparability between capitalist and socialist law explains the dramatic and sudden transformation of the discipline in the 1950s and $1960 \mathrm{~s} .{ }^{75}$ The theoretical refusal of the very comparability of two superstructures (such as the law) remained popular in the Soviet Union well after the purge of Pashukanis in 1937. Actually, after the erosion of the East-West relationships from early 1946, the tone of the Agitprop (the Department of Agitation and Propaganda of the Communist Party of the Soviet Union (CPSU)) became much more hostile, and various campaigns against "cosmopolitanism" were making it very difficult for Soviet scholars to even claim the superiority of socialist legality over bourgeois legality in the footsteps of Andrej Vishinsky. Getting materials from abroad, or even publishing in a language other than Russian, would expose a Soviet scholar to the potential accusation of servility to the West. Similar troubles were experienced by American scholars, whose independent research on the Soviet world was simply impossible under the regime of FBI and CIA campus surveillance, which included infiltration. ${ }^{76}$ The Cold War phantom was making self-censorship the rule on both sides of the Iron Curtain.

Western comparatists still convinced of the universalistic claim of their knowledge ${ }^{77}$ and eager to access international and area study money, developed a legal taxonomy capable at the same time of claiming a structural distinction between law and politics and the comparability of the socialist legal order with its bourgeois counterpart. Clearly, within this scenario, the description of the Soviet legal system in derogatory, or at least condescending, terms was not even a conscious move. It was simply the zeitgeist's impact on the profession of comparative law. Paradoxically, and

74. An updated discussion of the "three families" can be found in Schlesinger's Comparative Law 654 (Ugo Mattei, Teemu Ruskola \& Antonio Gidi eds., 7th ed. 2009).

75. The foundation of the American Journal of Comparative Law in 1952 has generated the intellectual infrastructure for this epistemic transformation. English rapidly became the lingua franca of the profession and the Journal (an Organ of the Society) was animated by Sovietologists such as Hazard and by the best refugee scholars by then in their full maturity. The Journal has determined the global Americanization of the comparative legal profession.

76. Abundant evidence for Columbia, Harvard, and Yale is offered by DiAmond, supra note 66 .

77. The critique of ethnocentrism of such kind of universalism was yet to reach the comparative law mainstream. Only from the late '90s of the last century did such a critique emerge at conferences organized at the University of Utah, University of Michigan, and University of California Hastings. 
especially in the United States, comparative law developed in those years both a higher degree of methodological sophistication and a full-fledged Wilsonian missionary spirit that the more rudimentary early work did not include. The Western comparative law community was attempting to shelter socialist colleagues from their presumed intellectual oppression while failing to recognize its own. The Faculté Internationale de Droit Comparé exuded this spirit to the very end of the Cold War. ${ }^{78}$

\section{The Tripartite Taxonomy and Its Variations}

Someone looking at the leading introductions to comparative law cited above will conclude that, in the $1950 \mathrm{~s}$, the discipline had reached its scholarly maturity by two different, though related moves. First, it had attempted to produce a taxonomy capable of grouping the legal systems of the world into families according to some organizing principle. Second, it had begun to challenge the excessively sharp tone of the distinction between common law and civil law. Both these moves, I submit, cannot be interpreted only as an evolution of the skills of the participant in the comparative law enterprise. Rather, they are the product of social and political processes driven to a significant extent by the specific historical conditions of the time-processes that produced ideology in the specific meaning of false consciousness, unveiled by the logical inconsistency of deploying at the same time the contrastive (with socialist law) and the integrative (common law/civil law) approaches.

Leaving aside the very complex (and quite futile) debate on the criteria according by which to classify legal systems into a family ${ }^{79}$ Soviet law emerged as an object of scientific comparison for the first time in the early taxonomies. In Schlesinger, it was the "third family" after common law and civil law; in David's version, it was one of the three families positively described (the fourth one being the "residual" family of "other conceptions of law"); in Zweigert and Koetz too, it maintained an autonomous status. Further, the criteria of distinction among the different families were vague, somewhat blurred, and linked to notions requiring quite a bit of belaboring to be understood (it took Merryman to clarify the meaning of style ${ }^{80}$ ). In contrast, socialist law was distinguished very clearly from capitalist law, a

78. I was a student of the Faculté in 1980 and later in the early ' 90 s a professor in the same institution that praised itself as being the only place where socialist comparative law scholars and students were "allowed" to meet capitalist colleagues for significant lengths of time. I remember rumors, of course void of any evidence, of reciprocal surveillance between socialist students and faculty.

79. See Schlesinger's Comparative Law, supra note 74.

80. See John H. Merryman, The Italian Style II: Law, 18 Stan. L. REv. 396 (1965-1966). 
distinction that only needed to extend to the law on which the opposition based the political-economic option to nationalize the means of production. Marx himself provided the criteria by describing the law as a superstructure of the class relationship. This genuinely Marxist aspect of Soviet legal identity, rejected during the debate over the comparability of Soviet law with capitalist law, while openly used in drafting the first comparative taxonomies, introduced more contradiction by denouncing the rather feeble scientific claim of comparative legal taxonomy. ${ }^{81}$

When comparative law had reached its "functionalist-structuralist" maturity, ${ }^{82}$ the unease of bourgeois comparatists about recognizing a genuine identity of socialist law as an alternative to capitalist legal arrangements emerged quite clearly. Sacco, for instance, in a famous article on the "civil law substratum" of socialist law, considered the most significant aspects of socialist legality as an addendum to a deeper civil law tradition, which, according to his analysis, was much more relevant in understanding socialist law then any work on the economic structure..$^{83}$ Even clearer was the ex post "confession" of Koetz. He did not stop short of just taking away the chapter on socialist law from his introduction in the third edition following the fall of the Berlin Wall, as if the political demise of the Soviet Union and the return of its Western satellites in the capitalist orbit was enough to consider the socialist experience historically irrelevant. Koetz wrote in the introduction that his erasure would spare the reader some sixty pages!

There are a variety of implications in this quite schizophrenic Western admission and denial of socialist legal identity as relevant for comparative law. Very evident is a degree of insistence on the central position of private law for purposes of comparison. The message is (a) only private law is genuinely law; and (b) public law is a contingency intimately connected with a positivistic state-centered vision.

These two Western-centric biases are indeed a self-fulfilling prophecy because the first conception happens to be the one developed in the Western legal tradition as an incident of the proprietary origins of Roman law. The second is the same enduring vision according to which the stronger is the government, the weaker the individual rights..$^{84}$

81. For a strong description of Soviet law as party politics, see JoHN N. HAZARD, Communists AND THEIR LAW (1969). This description of socialist legality as ultimately arbitrary is in the classic book by Otтo Kirchheimer, Political Justice: The Use of Legal Procedure for Political Ends (1961).

82. See Rethinking the Masters of Comparative Law, supra note 33.

83. See Rodolfo Sacco, The Romanist Substratum in the Civil Law of the Socialist Countries, 14 Rev. Socialist L. 65 (1988).

84. See Fritjof Capra \& Ugo Mattei, The Ecology of Law: Towards a Legal System in Tune With Nature and Community (2015). 
In such a strategy, long deployed by orientalists to deny legal subjectivity to China, public law can be added to and subtracted from the "real" legal system which remains rooted in the private law tradition.

In retrospect, this move, in deep contradiction with the most important theoretical results of the taxonomic phase of comparative law, is also a product of the dynamics of the Cold War. I refer here to the separation made by the early introductions to comparative law between Chinese law and Soviet law, where only the latter was considered a member of the socialist law family, while the former was classified in a different "family of legal systems" carved out of the orientalist criteria of static Confucian adherence and oriental despotism. ${ }^{85}$ It is quite clear that if China and its cultural orbit (Vietnam and North Korea) are denied socialist subjectivity, the political fall of the USSR can be extended to the whole socialist model, doing violence only to Cuba (and perhaps later to Venezuela) which can be easily dismissed because of the scarcity of the population.

The separation of the USSR and China into two different families of legal systems certainly reflects the scholarly tradition in Western academe, where Sinology and Sovietology are two understandably different domains of area studies (if for no other reason than linguistic barriers), distinct from the actual reach of MarxismLeninism. To be sure, if the criteria of classification were coherently political, there would be no reasons to consider China after 1949 as an outsider to the socialist family. ${ }^{86}$ However, one has to consider that Mao had just seized power nationwide when comparative law inaugurated the taxonomic era, and that not much was known about the genuinely socialist legal system introduced in the large part of the country under communist control since 1930 and during the Long March. ${ }^{87}$ China being largely rural, and the Cultural Revolution far off in the future, one could have argued (with categories developed later) that a traditional legal system was still hegemonic in the fifties in China. Moreover, other much more relevant historical processes were to separate China from the USSR when the issue of the succession of Stalin in international communist leadership arose in 1953.

While it is impossible to say whether comparatists would have kept China (and its orbit) outside of the socialist family if the Soviets had recognized Mao's leadership, it is a fact that the political division

85. See RusKola, supra note 62.

86. See id. There is no question that, especially after the launch of the Sputnik, the USSR was perceived as a much more serious competitor than Maoist China (which was easily "expelled" from the UN). Hence, once more the comparative law "status" of the two socialist countries was reflective of political determinations in the United States.

87. See Schlesinger's Comparative LaW, supra note 74. 
within the block was coherent with the comparative taxonomy at the time. Dividing political socialism in the perspective of comparative analysis has certainly helped in weakening socialist law as an alternative to the Western legal tradition (bourgeois legal phase if we wish to see it with socialist eyes). The heavy toll of this ideological move (no matter if strategic or just induced by political events) was to be paid after 1989 when legal Sovietology was all but dismantled and generalist comparative lawyers could seriously claim that the family of socialist law was extinct, in spite of over 1.5 billion people being ruled by communist parties worldwide..$^{88}$ Obviously, the number significantly increases if one considers, in addition to China, the populations of Cuba, North Korea, and Vietnam, as nations still ruled by post-socialist Leninist party organizations. However, the separation between China and the USSR was also a Cold War move to "divide and rule" intellectually, carried out throughout area studies, and which has precluded Western comparative law from genuinely understanding the communist conception of law.

Ultimately, the early taxonomies of comparative law show quite an interesting schizophrenia of adherence to (or critique of) Pashukanis and Vishinsky. Comparatists have sided both with the former, in agreeing that, ultimately, law is essentially private and commercial in nature, and with the latter, in seeing socialist public law as intimately connected with the new socialist bureaucratic state. ${ }^{89}$ Nevertheless, it has been the Cold War confrontation that carried the debate over taxonomy at the center of the comparative legal agenda. The ensuing unavoidable reflection on the political and geostrategic conditions of our comparative knowledge triggered later self-reflection at the fall of the Berlin Wall including some understanding of our own disciplinary ethnocentrism. ${ }^{90}$

\section{Comparability as a Bourgeois Critique to the Marxist Canon: Beyond Legal Positivism in Comparative LaW}

In a more general perspective, the taxonomic phase of comparative law meant going beyond legal positivism that had characterized the phase of législation comparée. Legal families, to be sure, needed organizational principles deeper than the mere contingency of legislation and of the official sources of law. No legislator or political authority can decide whether their own country belongs to common law or civil law, which are traditions as such (akin to the language

88. The Review of Socialist Law, first published in Holland in 1975 and which provided a forum for comparative discussion for Western Sovietologists (and which included articles on socialist countries outside of the USSR), abruptly changed its name in 1991 to become the Review of Central and East European Law.

89. See Collins, supra note 73.

90. See Ugo Mattei, Three Patterns of Law: Taxonomy and Change in the World's Legal Systems, 45 Aм. J. Comp. L. 5 (1997). 
spoken by the people) and beyond the reach of a legislator. ${ }^{91}$ Being a common law or a civil law country is not an arbitrary political choice; rather, it involves a legacy of history and deep structure. In this perspective, socialist law as a family of legal systems (or a legal tradition) creates some problems: one socialist revolution would not be enough to make a family of socialist law. ${ }^{92}$ Indeed, it took quite a while after 1917 for Western comparatists to speak about a family of socialist law. Socialist law was recognized, albeit reluctantly, as a legal family after quite a significant phase of experimentation, which included sophisticated intellectual debate over the relationship between law and socialism (the Pashukanis versus Vishinsky confrontation in the '30s) and original institutional construction (such as the Prokuratura or the different models of socialist property law)..$^{93}$

In a sense, the recognition of socialist law as a family of legal systems, which also gave rise to a fairly fundamental rethinking of the nature of the opposition between civil law and common law, was a hostile move in the Cold War context. ${ }^{94}$ In spite of the fact that Lenin was a lawyer, and actually a very good one, who, from the 1920s until his death, had contributed much to the development of global legal civilization and consciousness, ${ }^{95}$ Marxist theory reduced legality to a superstructure of the bourgeois system of production. Marx interpreted law as a contingent product of the bourgeois phase of capitalist development, something that a socialist system should deploy only as a lesser evil, but that is bound to disappear with the eradication of the class system. Marx never needed to distinguish common law from civil law; and Marxism, in opposition to the liberal agenda, uses class, not the individual person, as the social building block, with the consequence that socialist law is but an oxymoroncertainly not an autonomous institutional setting understandable in its own terms.

While Marx offered the theoretical foundation of this vision of law as a class-specific device of the bourgeoisie, it took Pashukanis, the Soviet legal scholar most respected in the West, to develop a full-fledged theory of law as a byproduct of the needs of contractual transactions and of the necessarily individualizing structure

91. See René David, Major Legal Systems in the World Today (1968). See also Patrick Glenn, Legal Traditions of the World: Sustained Diversity in Law (5th ed. 2014).

92. See Ugo Mattei, Socialist and Non-Socialist Approaches to Land Law in Somalia and Other African States, 16 REv. SocIALIST L. 17 (1990).

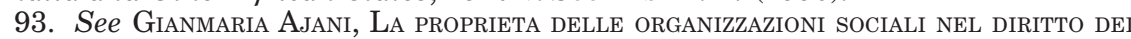
PAESI SOCIALISTI (1988); Boris N. Mamlyuk, Early Soviet Property Law in Comparison With Western Legal Traditions, in Research HandBook on Political Economy and LaW 454 (Ugo Mattei \& John D. Haskell eds., 2015).

94. See HAZARD, supra note 81.

95. See QuigleY, supra note 4. 
of the idea of commercial exchange. ${ }^{96}$ In Pashukanis's understanding, because law was structurally a product of the capitalist order, it would make little sense to compare it with the socialist order. ${ }^{97}$ Either we would be comparing a fading superstructure of a new socialist structure (socialist legality) with a superstructure in a previous phase, or we would compare two radically different structures (socialism and capitalism), which is not the task of a lawyer. Pashukanis was writing in a polemic with Peteris Stucka, the Chief Justice of the Soviet Supreme Court, who believed in the transformation of bourgeois legality into socialist legality as a consequence of the Revolution. Socialist legality, in Stucka's Hegelian vision, was the outcome of a dialectic between the bourgeois thesis and the revolutionary antithesis. Stucka was one of Lenin's most important legal advisers in the early phase of the NEP and, unlike Pashukanis, he denied the inextricable connection between law and capitalist commercial transactions. ${ }^{98}$

After Stalin's decision to consolidate socialism in just one country, the attitude of Soviet Russia toward law had changed dramatically, as Stalin incrementally deployed the law for political purposes, including the elimination of political opposition (the famous trial of Nikolaj Ivanovič Bucharin is a case in point) and campaigns of reeducation. Indeed, the use of legal decisions as devices of mass education on socialist legality is a recognized feature of the "style" of socialist law. ${ }^{99}$ The hero of Stalin's intellectual emancipation from traditional Marxist theory of legality as an exquisitely bourgeois project was Andrej Vishinsky who, in a radical critique of Pashukanis, theorized the inherent superiority of socialist legality as opposed to the bourgeois one. ${ }^{100}$ Socialism needs law permanently, he contended, as well as a strong state with a monopoly of the sources of law. ${ }^{101}$ Neither Stucka's idea of an instrumental use of law in transition, nor the genuinely Marxist vision of a fading of law and state in transition to communism, could serve the conservative turn taken by Stalin. To Vishinsky, law was not a lesser evil but rather a noble device allowing for the organization of a permanently structured socialist state. A drastically teleological vision of law as a means to a political end emerged in the wake of the dramatic events that took place between Lenin's (and Stucka's) death in 1924 and Pashukanis's

96. See Collins, supra note 73. See also Mamlyuk, supra note 93; HARold J. Berman, Justice in the USSR: An Interpretation of Soviet LaW 20 (1963).

97. See Pashukanis, supra note 29.

98. See Peter I. Stucka, Selected Writings on Soviet Law and Marxism (Peter Maggs et al. eds., 1988). For a discussion and a rich bibliography on the role of ideology in the making of the Soviet legal family, see Gianmaria Ajani, Diritto Dell' Europa Orientale, in Trattato Di Diritto Comparato 35ff. (Rodolfo Sacco ed., 1996).

99. See International Encyclopedia of Comparative LaW, supra note 69.

100. See Andrey Y. Vishinsky, The Law of the Soviet State (1948).

101. For a critical reading, see Gianmaria AJANi, Le FONTI NON SCRITTE NEL DiRitTo DEI PAESI SOCIALISTI (1985). 
execution in 1937. In spite, or maybe because, of these events (which included the promulgation of the Soviet Constitution in 1936), the idea that "socialist legality" was little more than camouflaged political expediency remained strong in the Western perception of Soviet law. The description of the socialist legal family in Western comparative law books as "lacking" the rule of law is perfectly compatible with the quite banal critique of Vishinsky to Pashukanis. ${ }^{102}$

Pashukanis's vision triggered the early theory of non-comparability of socialist and bourgeois law, advanced by many socialist legal authors (the best known being A.A. Tille), influenced by Pashukanis's school, which was in its heyday at the peak of the Cold War. According to this vision, coherently based on a notion of law as a superstructure of the process of production, there is simply no meaningful comparison possible on the analytical ground between prerevolutionary, bourgeois law and the socialist model. ${ }^{103}$

Interestingly, Vishinsky's opposing vision also led Soviet comparative jurisprudence to the same results of denying meaningful comparability. This time, the denial was based on normative rather than analytical grounds. Socialist law was "inherently superior" to previous and contemporary bourgeois law, as an expression of the people at a more advanced stage of political development. Any scientific comparison with bourgeois law, other than the mere accumulation of evidence in support of this truth, would be meaningless, since socialist law had nothing to learn from its capitalist neighbors. ${ }^{104} \mathrm{~A}$ science of comparative law could only emerge in the study of the different ways in which the different Soviet republics pursued the same task of building a sturdy socialist system of state and law. ${ }^{105}$

The fundamental agreement on non-comparability flourished practically unchallenged on the Eastern part of the Iron Curtain through the Cold War. Of course, Western comparatists, who dealt with the issue, discussed nuances developed over time and space across the socialist law family. ${ }^{106}$ For instance, they detected some limited openings in post-Stalinist USSR due to an increase in academic dialogue, especially with Central European scholars at the

102. See Berman, supra note 96 , at $20 f f$.

103. Anatolit Tille, Sotsialisticheskoye Sravnitelnoye Pravovedenie (1975).

104. See P.S. Romaskin, Amnistija i Pomilovanie v SSSR 2, 144 (1959) (as cited by AJANI, supra note 93, at 53):

Soviet jurists that together with Western colleagues take part in organizational activities in the domain of comparative law must remember that their role is to promote the diffusion and the knowledge of the Soviet conception of the law and of its historical superiority. They should never (as unfortunately sometimes happens) find out analogies between Soviet and bourgeois law outside of that purpose.

105. See A.F. Chebanov, Science du droit comparé en USSR, 27 RevUe INTERNATIONALE DE DROIT COMPARÉ 121 (1975).

106. See AJANi, supra note 93 , at $49 f f$. 
periphery of Soviet law. However, the single most important issue addressed by comparatists dealing with the Soviet-capitalist divide was the discussion of whether it was possible to compare the two to begin with. ${ }^{107}$

I submit that a number of features of Western comparative law have been determined by a professional desire to confront the issue of non-comparability with a number of mirror moves. First, by making Soviet law one of the world legal families in all the early taxonomies constructed in comparative law, comparatists were showing that a scientific comparison was actually possible because they were not "afraid" of the deep differences. ${ }^{108}$

Second, by emphasizing the extraordinary complexity, richness, and sophistication of the theories of sources of law in common law and civil law, comparatists could point at the "underdevelopment" of the Soviet theory of the sources of law as a matter of continuity between prerevolutionary tsarist and postrevolutionary socialist law. ${ }^{109}$ Thus, with just one move (emphasizing the sources), they could hit two targets. First, they could claim that discontinuity was just revolutionary ideology, because politics can never completely determine the legal system in its autopoiesis. ${ }^{110}$ Second, they argued for the superiority of Western jurisprudence, and more generally of the Western model of liberal democracy considering it a pluralistic system with an open and highly theorized understanding of the formal and informal sources of law. This feature, in opposition to the rudimentary state-centric Stalinist vision, was a common aspect of both the common law and the civil law traditions. Such a politically motivated analysis by Western comparatists contributed a great deal to moving comparative law beyond the black letter stage.

Thus, because of the Cold War, the critique of legal positivism, which remains today a distinctive methodological trait of comparative law, made, at the beginning of the taxonomic phase, a significant step forward. If a legal system is taken in its complexity, the legislator cannot be seen as the ultimate sovereign. Soviet law simply cannot choose discontinuity or declare incomparability, since in a correct scientific perception, it is quite different from the monolithic

107. On the contents of a 1958 meeting of the International Association of Legal Sciences held in Warsaw with some admissions that the comparative method could be deployed in comparing laws stemming from different economic structures, see Janos Tòth, Comparative Law in Eastern Europe, 2 J. INT'L CoMm'N JuRISTs 245, 250ff. (1965). 108. See this doctrine as restated by Sacco, supra note 45.

109. The idea of continuity between tsarist autocracy and communist party rule is a classic topos of U.S. Cold War rhetoric. See, e.g., Richard Thornburgh, The Soviet Union and the Rule of Law, 69 Foreign AFF. 18 (1990).

110. See Harold Berman, Law and Revolution: The Formation of the Western Legal Tradition (1983); James Gordley, Myths of the French Civil Code, 42 Am. J. Comp. L. 459 (1994). 
description offered by domestic lawyers. ${ }^{111}$ These lawyers are either ideologically driven or fearful of the political consequences of their actions in a totalitarian society. In the real life of the law, scientifically understood through correct methods, there is no such thing as a supreme sovereign ruler capable of deciding the law that remains autopoietic by nature. There is a limit to what a sovereign can choose, even if he is Stalin (or Napoleon before him). Certainly, the ruler cannot decide to what legal family his state belongs. A declaration of that kind would be as ridiculous as that of Woody Allen's dictator in Bananas declaring to an astonished Spanish-speaking population that from now on the official language would be Swedish!

A direct consequence of this scientific claim of comparative law as a self-perceived methodology capable of objective, nonideological choice is the division of the socialist block into two separate families. Even before the political break-up of the USSR and China (over international leadership in the socialist world in the wake of Stalin's death), both David and Zweigert and Koetz had decided that China would not be part of socialist law. In a paradigmatic orientalist move, which, since Hegel, had denied China any capacity to evolve away from the Confucian worldview, the early scientific comparatists insisted on firmly locking the "far eastern" Chinese legal system in the orbit of "other conceptions" of law. ${ }^{112}$ Again, it was a Cold War move to divide the socialist world. A move whose clear ideological inspiration (dubbed scientific) proved useful to legitimize the all but total erasure of socialist law from the global map of legal systems that followed the dissolution of the Soviet Union in 1991. As mentioned before, Hein Koetz followed exactly that strategy when, right after the German unification, he simply omitted the chapter on socialist law from the new edition of his classic, coauthored with Konrad Zweigert. Interestingly, that hasty move was in blatant contradiction to the claim of continuity and insufficiency of political determination in front of the complexity of the sources of law that comparatists had deployed before: the end of history in comparative law!

\section{The Common Core of Legal Systems}

What was the correct scientific method that Western comparatists could deploy while their ideologically driven colleagues on the other side of the Iron Curtain could not, for fear or intellectual inferiority? To be sure, until the 1950s the comparative law scholarly community had little intellectual sophistication to display with pride. ${ }^{113}$ Comparative law had just entered its taxonomic phase

111. AJANI, supra note 93 .

112. See Schlesinger's Comparative Law, supra note 74.

113. Full awareness of this state of affairs is displayed in the preface to SCHLESINGER, supra note 39. 
and, in retrospect, we know it did it with a blatant display of ethnocentrism. True, Schlesinger and Gorla (on Rabel's shoulders) were already beginning to deploy an impressive factual method of inquiry in an effort to actually compare, rather than merely juxtapose, different systems; however, it was not until the end of the decade that the common core became recognizable as a full-fledged methodological step forward in our discipline. ${ }^{114}$

Interestingly, while David and Zweigert and Koetz were still using a fundamentally contrastive approach to comparative law, just shifting the "formidable intellectual barriers" from the national boundaries of the different states to those between different families of legal systems, Gorla and Schlesinger (with Lorenz and Bonassis) where inaugurating an integrative era, where the focus on analogies was much more powerful than that on differences. ${ }^{115}$ Both these approaches owed much to the Cold War climate. The contrastive construction of socialist law as a legal family significantly different from (and smaller than) the reach of political socialism, ${ }^{116}$ allowed comparatists to make two claims. First, political choices are weaker than cultural traditions. ${ }^{117}$ Secondly, the comparative professional project was not afraid of deep differences because comparison across families was still possible, and comparing a socialist country with a common law or civil law one was no more difficult than comparing any European legal system with, say, an African or an Asian one, regardless of the political context. In the contrastive vision, moreover, there was a not so well hidden bias in favor of the higher degree of legal civilization of the common law and of the "more advanced" civil law jurisdictions, to use the terminology that appeared in the first casebook of comparative law, i.e., Schlesinger's masterpiece. ${ }^{118}$

114. The methodological issues and the "improvement" in the canon of research is discussed already at length in Rudolf $\mathrm{B}$. Schlesinger, The Common Core of Legal Systems: An Emerging Subject of Comparative Study, in TwentiEth-Century Comparative and Conflicts Law: Legal Essays in Honor of Hessel E. Yntema 65 (1961). An impressive bibliography on work about the common core before the publication of the results of the Cornell seminars with some twenty articles published worldwide between 1957 and 1967 can be found in Formation of Contracts, supra note 65, at $62-65$.

115. See G. Gorla, La "logica illogica" del consensualismo o dell' incontro dei consensi e il suo tramonto, 12 RivisTa DiritTo Crvile 255 (1966).

116. See John D. Hazard, The Soviet Pattern Spreads Abroad, U. ILL. L.F. 277 (1964).

117. This was, as discussed, the justification to keep China outside of the family. See id.

118. Schlesinger, supra note 39. Already in the first edition, he displays the idea that the most meaningful comparison (worth undertaking to learn from foreign experience) is that between systems with comparable degrees of development. In the Introduction to FORMATION OF CONTRACTS, supra note 65 , at 22, Schlesinger cites Italian scholar Tullio Ascarelli in a claim that methodologically sophisticated comparative law boils down to a dialogue between common law and civil law to discuss the Cornell treatment of Islamic and Egyptian law as "developing legal systems." 
It would be difficult to deny that the most important and characteristic methodological step forward in our discipline was the inauguration of the integrative method of the common core approach at Cornell. ${ }^{119}$ Schlesinger headed the project, which inquired into the issue of contract formation, as a Ford Foundation project for some ten years. The project attracted many international scholars to Cornell (including Gino Gorla), and generated an impressive twovolume publication, which has since set the standard for functionalist integrative comparative law. The treatment of "communist law" (this was the term used in the publication) at Cornell requires some expansion. To begin with, Schlesinger shared the idea that communist law was a family of legal systems. Interestingly, that was the only family treated as such in the "communist legal systems annotations," the only ones in the two volumes organized by family and not by nationality. Second, in a footnote to the introduction, Schlesinger seems to believe that for the purpose of his study, the communist family includes China, where "the position (in the early 1960's) does not seem to have been radically different." ${ }^{20}$ Third, the only legal system in that family that the project actually discusses at length is Poland, thanks to the help of W.J. Wagner, a Western-trained Polish professor in the faculty at Indiana.

Schlesinger explicitly correlated the issue of inclusion or exclusion of communist law with that of comparability of contract law in a planned as opposed to market economy. He devoted a few masterful pages in his introductory chapter on socialist legal systems, ${ }^{121}$ and, while acknowledging the "seriousness" of the issue of (un)comparability, ${ }^{122}$ he undertook a typically functionalist examination of the question, with all the sophistication that made him the undisputed global master of the field for a half century. The objective of the Cornell project was to "[s]tudy the contract law of several socialist nations for the very purpose of determining comparability. In other words, the question of comparability was to be determined after, and not before, an attempt to compare." ${ }^{23}$ The issue eventually was "solved," based on the tremendous authority of the common core project, unsurprisingly in favor of scientifically determined comparability (as opposed to ideological incomparability). The question, which

119. On its potential for current days' inquiry, see Mauro Bussani \& Ugo Mattei, The Common Core Approach to European Private Law, 3 CoLum. J. Eur. L. 339 (1998).

120. Schlesinger, supra note 39 , at 24 n.16.

121. Formation of Contracts, supra note 65 , at 211. Schlesinger refers to further discussion to his cited 1961 article. He seems to use the term communist and socialist as synonymous.

122. "Western scholars though not subscribing to the ideological premises underlying this view of their socialist colleagues, have to admit that there is a question of comparability which requires a serious examination." Id. at 23 (citing RENÉ DAVID \& Günther Grassman, Einführung in die grossen Rechtssysteme der Gegenmwart (1996)).

123. Formation of Contracts, supra note 65, at 23. 
was as ideological (or unideological) in the West as it was in the USSR, had been on Schlesinger's mind for quite a long time. Already in July $1961,{ }^{124}$ he travelled to Trier, where no less than Joseph Esser (one of the towering figures in the critique of legalistic positivism) had organized a discussion (sponsored by the International Association of Legal Sciences ${ }^{125}$ ) on the comparability of legal institutions in the field of contract and property.

In his common core discussion of communist law, Schlesinger would not go as far as to deny that the subject matter of contract formation-the core of private law-raised research questions that would not do justice to the specificities of socialist legality, tailored as it was on economic planning:

For the purpose of discussion, the argument against comparability may be stated in the following over-simplified form: 1. In a socialist economy contracts governed by the civil code or by similar provisions of private law are of practical importance only within a strictly limited sphere of economic activities. 2 . The important transactions are those concluded among socialist enterprises in fulfilment of a Plan, and such transactions are not comparable to private contracts of the traditional type. Hence, it follows 3 . That what is comparable in this area is relatively unimportant and what is important is not comparable. ${ }^{126}$

To Schlesinger, the answer to this simplistic syllogism is in the key characters of common core research, the very methodological step forward that his sophisticated method of inquiry was contributing to comparative law:

Closer examination shows, however that this argument is based on unwarranted generalizations. In the first place, the various "socialist" systems differ from each other in their treatment of contracts between socialist enterprises ... even with respect to the countries which adhere to a more conservative reading of socialist doctrine it appears that neither part 1 nor part 2 of the argument can be maintained without serious qualifications throwing doubt on the soundness of the conclusion. ${ }^{127}$

124. See Rudolf B. Schlesinger, Trier Conference on Comparative Law, 10 Ам. J. Comp. L. 508 (1961).

125. The Association, grouping together the various national organizations of comparative lawyers, is another Cold War-generated institution aimed at demonstrating comparability and ultimately the scientific and nonpolitical nature of legal comparativism. Founded in 1950 as the International Committee of Comparative Law of UNESCO, it received its current name in 1955 and remains under UNESCO auspices with its seat in Paris where the UNESCO headquarters are located.

126. See Formation of Contracts, supra note 65 , at $22-23$.

127. Id . at 25. As to countries not adhering to the conservative vision, Schlesinger cites Yugoslavia. 
It would be beyond the scope of this Article to follow the master in introducing all the relevant qualifications of contract law, both in its codified form and in its practice, that would appear relevant "to ascertaining the common core of legal systems" within the socialist and capitalist purview. Especially interesting is Schlesinger's analysis of Kontrahierungszwang (compulsion to contract) as developing in capitalist countries that may show a convergence with the contractual duties of the plan. ${ }^{128}$

It is exactly in this analysis, aimed to show in practice the comparability among systems with very different substantive sources of law (and even ideologies) that the common core hypothesis, appears at its best. ${ }^{129}$ Far from politically neutral, and clearly imbedded in scientific positivism in the best tradition of American Legal Realism, Schlesinger moves gigantic steps forward away from juxtaposition to comparison.

The old pre-taxonomic tradition of comparative law has proved incapable of thinking outside the box of the jurisdictional boundaries between the states because the early students of législation comparée simply reflected that the "formidable intellectual barriers" between states created by codification in the civil law and by the demise of Latin as the legal lingua franca in the continental European tradition. David's and Zweigert and Koetz's contrastive taxonomic approach challenged state positivism, but it certainly bought into many of the common places of the previous phase. These early scientific comparatists portrayed the opposition between common law and civil law as one of magnitude, comparable to that between a capitalist and a socialist organization. It was only with the integrative approach of the common core that comparative law was able to move beyond taxonomy and into actual comparison based on a single standard for both capitalist and socialist legal systems. This approach allowed a first fundamental distinction between laws in action, as applied to real-life cases, and the description of the law produced by the very different forms it takes in the different legal families. Comparative law, short of remaining a mere tool for gaining a more international perspective, as it had been done in the United States since the early twentieth century, became a thorough effort of actual comparison of practical solutions. In struggling to reach an

128. Schlesinger, to make his point, cites towering figures of Western private law scholarship: André Tunc, La possibilité de comparer le contrat dans des systèmes juridiques à structures economiques différentes, 27 RABELSZ 478 (1962); Frederich Kessler \& Edith Fine, Culpa in Contrahendo, Bargaining in Good Faith, and Freedom of Contract: A Comparative Study, 77 Harv. L. Rev. 401, 409-12 (1964).

129. Much later in the Common Core of European Private Law Project (launched in 1993 and still ongoing) we would talk about "meta-legal formants" to spell out the relevant contextual differences. The terminology is borrowed from Sacco, supra note 45. See Ugo Mattei, The Comparative Jurisprudence of Schlesinger and Sacco: A Study in Legal Influence, in Rethinking the Masters of Comparative Law, supra note 33; Bussani \& Mattei, supra note 119. 
unbiased factual hypothesis to base discussion on, comparatists at Cornell were actually fine-tuning their methodology and discovering an impressive number of factors relevant for an effort to avoid prejudices created by the unexplored biases of each national professional tradition. ${ }^{130}$

The inclusion of communist law in the study of the formation of contracts-the subject of the Cornell seminars-was a bold step beyond the sterile methodological discussions that were taking place (and were to continue well into the eighties) between comparatists both in the capitalist and in the socialist world. A passion for idle methodological discussion, brilliantly diagnosed as a product of the Cinderella complex of our discipline, has certainly contributed quite a bit to its painful irrelevance. ${ }^{131}$ However, the inclusion of Soviet law in the volumes on formation of contracts was more than that. It was a demonstration that meaningful comparison was actually possible in law, regardless of the ideological self-image of any legal system. Was this really true? Was the rethinking of the opposition between common law and civil law itself an ideological Cold War move? Was the image of convergence, that powerfully emerged from the Cornell seminars, a simple way to claim the superiority of Western law (or at least of Western comparative law) in a moment in which Soviet legal comparatists were weakened by the dogma of state sovereignty over the sources of law, and by their own consequent difficulty in finding meaningful comparison?

No matter what the answers to these questions might be, it is a fact that as a byproduct of an ideologically inflected preliminary discussion on the choice of the legal systems to be discussed and the contributors to be invited to Cornell (using Ford Foundation and Carnegie Endowment money), Western comparatists were forced to think about foundational questions related to the very purpose of law in society. Asking deep questions has produced deep answers, well beyond the mere issue of the comparability of contract law.

\section{The Private Law Bias of Comparative Law}

After decades of work in integrative comparative law, "on the shoulders of Schlesinger," 132 we have learned a number of lessons. The most important one is that the questions you ask determine the answers you get. The awareness of this, which now seems quite banal, was (and still is for many) painful to reach. One diehard byproduct of the common core methodology, certainly borrowed from

130. See Rodolfo Sacco, Un metodo di lavoro nuovo: I seminari di Cornell, 2 RIvisTA DiRitTo Civile 172 (1972).

131. Frankenberg, supra note 10.

132. See Vivian Curran, On the Shoulders of Schlesinger: The Trento Project on the Common Core of European Private Law, 11 EUR. J. PRIV. L. 66 (2003). 
the Parsonian sociological approach (itself very much instrumental to Cold War confrontation), ${ }^{133}$ was the idea of the possibility of a perfectly unbiased, neutral, and fully depoliticized objective analysis, if only one would properly apply the functionalist case method. To be sure, Schlesinger never made this claim, and it was read into his work by Sacco and a wave of mostly Italian "structuralist" comparatists, who attempted to move comparative law from functionalism into a structuralist phase, with the goal of measuring the similarities and differences. ${ }^{134}$ As we know in retrospect, the idea of "measuring" institutional differences was mostly responsible for attracting comparative law into the orbit of the dominant U.S. brand of law and economics, with the naively unforeseen result of the legal origins theory sponsored by the World Bank in the aftermath of the fall of the Berlin Wall. ${ }^{135}$ However, even stopping short of reaching these extremes, a certain conviction of the possibility to distinguish an analytic (positive) comparative law from a normative one remains dominant even today in spite of much discussion. ${ }^{136}$ This is a translation into comparative law of a positivistic bias of social sciences (and of course of economics), despite the claim that legal positivism was all but defeated already in the taxonomic phase of our discipline. To be sure, the meaning of positivism in the legal tradition and in that of the social sciences overlap only partially, ${ }^{137}$ so that we can say that after the taxonomic phase a more advanced positivistic phase of the discipline emerged. It is no surprise, or scandal, that Schlesinger himself shared with his fellow legal realists the idea of clear severability of the world of what "is" from the world of what "ought to be." However, he never fell short of introducing bold arguments of superiority of certain solutions over certain others, like he did in the famous Buffalo Law Review piece on criminal procedure in 1977. ${ }^{138}$ Nor it is a surprise that he was a true believer in the possibility of separating politics from law and the rule of man from the rule of law. He had survived quite fortunately the rise of the Führerprinzip (the rule of man) and became so genuinely grateful to the country where he had found safe haven as to buy into the rhetoric of the rule

133. Talcott Parson was the most prominent U.S. sociologist through the 1950 s and '60s. His role in making Harvard a CIA-friendly campus is not disputed among scholars of the period.

134. See Grande, supra note 28; Ugo Mattei, Comparative Law and Economics (1997).

135. Instructive of this contamination is the selection of materials in the recent Comparative Law and Economics (Giovanni B. Ramello \& Theodore Eisenberg eds., 2015).

136. See Symposium, New Approaches to Comparative Law, Utah L. Rev. (Special IssuE) 259 (1997) (held at the University of Utah Law School in October 1996).

137. Mattei, supra note 90.

138. See Rudolf B. Schlesinger, Comparative Criminal Procedure: A Plea for Utilizing Foreign Experience, 26 Buff. L. Rev. 361 (1977). 
of law, a darling of the North American psyche. ${ }^{139}$ The role of immigrant legal scholars in the professional foundation and development of comparative law in the United States (including the incorporation of what is today the American Society of Comparative Law) is well-known; ${ }^{140}$ as is also the role of many of such scholars, particularly the refugees from Soviet Russia, in providing intelligence about the enemy as well as materials for the early projects of annexation of social science to Cold War needs, such as in the projects Troy and Camelot. ${ }^{141}$ These factors, along with the phantom of the Cold War hovering over the years of McCarthyism, and the presence of John Hazard at Columbia Law School, where Schlesinger went through his second round of legal education, must have brought the young Schlesinger to suspend, at least in part, his critical and inquisitive spirit when it came to comparing Soviet law (often described as ideological) with capitalist law (described as scientific). Bringing Soviet law within the scope of inquiry into the common core of legal system was consequently not so much an inclusive move as it was actually a way to show a certain underdevelopment (very much expected given the subject matter) of communist law, as compared to the more advanced Western jurisdictions. True, it made a lot of sense in Schlesinger's agenda to show that even an outlier like socialist contract law could illustrate the prevailing similarities rather than differences when compared to systems belonging to the capitalist legal families. This was a smart move toward the depoliticization of the comparative legal discourse. However, the move made sense in the historical context only because comparative law was traditionally and severely biased in favor of private law. ${ }^{142}$ Finding a common core in contract law between capitalist systems organized around the exchange value and socialist ones organized around the use value, was an explicit critique of historical materialism. Nevertheless, it was a critique that could work only because the object of observation was the form of contract law, not its economic substance. ${ }^{143}$ The private law bias of comparative law (where most of the deeply studied structural differences are located) made the inclusion of Soviet law

139. See Rudolf B. Schlesinger, Memories (Ugo Mattei \& Andrea Padi eds., 2000).

140. See David S. Clark, American Participation in the Development of the International Academy of Comparative Law and Its First Two Hague Congresses, 54 Ам. J. Comp. L. 1 (2006); David S. Clark, The Modern Development of American Comparative Law: 1904-1945, 55 Aм. J. Comp. L. 587 (2007).

141. See, e.g., Diamond, supra note 66.

142. For the emergence of the critique of the "private law bias" of comparative law, see Ugo Mattei \& Mathias Reimann, New Directions in Comparative Law, 46 Aм. J. Comp. L. 597 (1998). See also Elisabetta Grande, Italian Criminal Justice: Borrowing and Resistance, 48 Ам. J. Comp. L. 227 (2000).

143. See John D. Hazard, Socialist Law and the International Encyclopedia, 79 Harv. L. Rev. 278 (1965). See also Gabriele Crespi ReghizZi, Limpresa nel DiRitTo soviETICO (1969). 
at Cornell a self-fulfilling prophecy of superiority of the core of capitalist law. ${ }^{144}$

For the purpose of this Article, I do not need to spend more time on this matter. One can only note how a Cold War urgency, while producing the important methodological step forward of developing a sophisticated functionalist approach to our discipline, nevertheless reinforced one of the key aspects of Western comparative law: its private law bias.

\section{The Roman Law Substratum of Socialist Law}

The strongly held belief in the "rule of law" as an undisputable segregation between the domains of law and politics, together with the deeply engrained private law bias of the discipline, are two mutually reinforcing characteristics of comparative law connected with issues of the Cold War. To be sure, Western comparatists specializing in Soviet law did not do much to overcome these biases. ${ }^{145}$ Indeed, the work of legal Sovietologists, rather than an attempt to learn from one another and to broaden the perspective of the discipline, was closer to a sort of external description of an objectified reality, a socialist legal family, whose subjectivity was all but denied. Western Sovietologists simply assumed that Western law had little to learn from socialist legality. ${ }^{146}$ Indeed, seen from the perspective of Western comparative lawyers, socialist law was little more than a reduced domain of application of a civil law substratum in areas such as economic planning, that a brutal and corrupt regime would politically claim were governed by a genuinely different form of law. ${ }^{147}$ Everything that could not be described as an application of this substratum, a sort of irresistible continuity that makes any form of revolution impossible in the law, was simply ridiculed as regime propaganda. ${ }^{148}$ Intellectual giants, such as Stucka, who in the 1920 s were deploying sophisticated Hegelian tools to describe a dialectical discontinuity between pre-Soviet and post-Soviet legality, were never considered as interlocutors, only described as actors (or victims) on a tragic and dramatic historical stage.

144. A similar strategy has been deployed also in different domains in the era of legal globalization. See Ugo Mattei \& Luca G. Pes, Civil Law and Common Law Towards Convergence?, in The Oxford Handbook of Law and Politics (Gregory A. Caldeira, R. Daniel Keleman \& Keith E. Whittington eds., 2008).

145. See, e.g., HAZARD, supra note 81. More balanced was probably Berman (supra note 96 ), although the strategy of blaming the political authoritarianism of Stalin on law was itself quite biased. Nobody has ever blamed Napoleonic autocracy on the French Civil Code.

146. See HAZARD, supra note 81.

147. See Sacco, supra note 83.

148. This is the dominant gist, for example, of the Review of Socialist Law published in the Netherlands, whose name was quickly changed at the end of the Cold War with the very same implications that we have already discussed for Zweigert and Koetz. 
The self-serving nature of this attitude toward socialist law seems quite clear. The geographical scope of socialist law was much broader than the discourses on the civil law substratum were willing to admit. Socialist law would not coincide with the boundaries of the legal family that Western comparatists had built for their own taxonomic purposes and needs to make the discipline "scientific." However, the Urals were not a barrier against the influence of the Soviet model. ${ }^{149}$ Only beyond them did socialist law encounter legal substrata that had nothing, or very little, to do with the civil law tradition. The Soviet Union was much broader than its European component. Many republics within it had experienced Islamic law, and never had anything to share with the Central and Western European legal traditions. Soviet jurist of such republics certainly were not nostalgic for a period in which they could be seen as integrated into the Western legal tradition, as was arguably the case (and indeed explainable because of previous class belonging) of some of their Hungarian, Polish, and Rumanian colleagues. ${ }^{150}$ The extent of socialist legal influence was moreover very broad and quite diverse, ranging from Asia, to the Middle East, Africa, and Latin America.

In retrospect, there would admittedly have been much to learn from the way in which socialist legality attempted to deliver emancipation, desegregation, labor, and property reform. Yet there was not such an attitude in the circles of Western comparatists. It took Quigley, long after the fall of the Berlin Wall, to show the kind of comparison that was going on at the geopolitical level. Moving away from a tradition of export-comparativism inaugurated in the United States at least since the Wilsonian "white man's burden" rhetoric, Quigley was able to show how much Western legal innovation benefited from examples from the other side of the Iron Curtain. ${ }^{151}$ However, professional comparatists busy in private law technicalities, missed the broader picture and yet another possibility for some relevance.

\section{The Convergence Hypothesis}

Comparatists usually explain the "convergence hypothesis" in comparative law ${ }^{152}$ as the product of a more critical look, in the age of

149. See Hazard, supra note 116.

150. The most prominent socialist scholars invited to teach short introductions to socialist law at the Faculté Internationale in Strasbourg were Eastern European and not Russians. One should name at least Victor Knapp, from Prague and György Peteri, from Budapest. Among those that obtained preeminence in Western comparative law, one should mention at least Mirjan Damaska (Yugoslavian) at Yale and Leontin Constantinesco a Romanian immigrant to France. An American scholar of Eastern German origins, Inga Markovitz, has also reached preeminence in U.S. academia.

151. See Quigley, supra note 4. See also Mary Dudziak, Desegregation as a Cold War Imperative, 41 StAN. L. REv. 61 (1988).

152. See Mattei \& Pes, supra note 144 
"integrative" comparative law, at the established strong oppositions between common law and civil law, especially in the domain of the sources of law. ${ }^{153}$ For example, the doctrine of stare decisis, traditionally weaker in the United States, was quite dramatically relaxed also in England in the aftermath of the Practice Statement of the House of Lords in 1966. Meanwhile, case law became increasingly significant in the civil law tradition, especially due to the growing role of the European Court of Justice and of the constitutional courts in most jurisdictions. The rising number of special statutes in the civil law tradition helped to somewhat weaken the central position of the civil codes, while in both the United States and the United Kingdom, some important pieces of legislation, such the 1925 Law of Property Act or the 1952 Uniform Commercial Code, could hardly be seen as simple narrow exceptions to the common law. ${ }^{154}$ These transformations, very visible in an era that Guido Calabresi has significantly dubbed "the age of statutes," 155 have led to the emergence of rather similar interpretative techniques that have also contributed to the fading of some classic areas of divergence between common law and civil law. Deploying a methodology pioneered by Alan Watson, a Roman law scholar whose main agenda in comparative law was to disentangle law from the social and political reality, comparatists have mostly explained this disentanglement by means of legal transplants ${ }^{156}$ or of a dialogue between the common law and the civil law.

The Cold War hypothesis suggests a different explanation. The phantom of the Cold War had produced a political urge in the capitalist block to portray the Western legal tradition as the historically accomplished epiphany of the rule of law, as opposed to the rule of man, Hitler's vile doctrine. The ideological apparatuses of the Cold War could deploy this rhetoric, already successful in determining U.S. legal hegemony in the aftermath of World War II, ${ }^{157}$ against the USSR. Especially after Nikita Khrushchev's denunciation at the XXth Congress of the Communist Party in 1956, it was easy to portray the institutional structure of so-called "democratic

153. See James Gordley, Common Law und Civil Law: Eine Uberholte Untersheidung, 2 ZeITSCHRIFT FÜR EUROPÄISCHes PRIVATREChT 498 (1993). In a broader perspective that introduces the notion of "integrative" comparative law, see Schlesinger, supra note 35.

154. See, e.g., Mauro Cappelletti, The Doctrine of Stare Decisis and the Civil Law: A Fundamental Difference or No Difference at All?, in FestSCHRIFT FÜr KonRAD Zweigert: Zum 70 Geburtstag 381 (Herbert Bernstein et al. eds., 1981).

155. See Guido Calabresi, A Common Law for the Age of Statutes (1982).

156. See Alan Watson, Legal Transplants: An Approach to Comparative Law (1974). It would be beyond the scope of this Article to show how the vision of "legal transplants" determined by "prestige" can be seen as a neocolonial and orientalist strategy itself aimed at depoliticizing the field. See Mattei, supra note 48. See also ElisabeTTA Grande, ImitaZione E DiRitTo: IPotesi sulla Circolazione DEI MODElli (2001). A discussion can also be found in Schlesinger's Comparative Law, supra note 74, at 223.

157. See Mattei, supra note 48; Mattei, supra note 6. 
centralism"158 as a dictatorship. There was a need to construct a tidy separation between law and politics, an achievement that according to the dominant narrative in comparative law was possible only within the domain of liberal democracy, shared by the more advanced countries of both the civil law and the common law families.

Comparatists bought into the rhetoric of the structural superiority of the rule of law (again shared by both common law and civil law) and of its political neutrality. "Where men rather than laws govern, people usually find it more prudent to seek a powerful human protector than to stand on legal rights against the State," writes Schlesinger the 1988 edition of his book, just one year before the fall of the Berlin Wall. ${ }^{159}$ Hans Baade, ten years later, in the sixth edition of the celebrated casebook, developed this most cursory attempt to describe the essence of the Western legal tradition, in contrast with both the Soviet Union and China. The outcome was a self-serving self-portrait displaying some faith in the idea that only Westerninspired legal institutions could produce an acceptably "democratic" social organization. In other words, showing convergence meant claiming that on what "really matters" (democracy, human rights, and the rule of law) the most advanced countries do agree, and every alternative is hopelessly bound to a dark phase of human history. ${ }^{160}$

It would have been useless to engage in such mirror imaging if comparatists could still comfortably stick to the technical comparison of professionalized law as they did until the 1950s, when the "rule of man" was certainly the reality in most European contexts. Rather, it has been the Cold War confrontation to provide the incentives to distillate a fundamental "structural" analogy of all Western countries to contrast them with the socialist block. In this way, the integrative and the contrastive methodology, short from being historical phases in the unfolding of the comparative legal narrative, ${ }^{161}$ are indeed powerful synchronic weapons. Convergence hypothesis in comparative law developed precisely for the ideological needs of contrasting the capitalist with the socialist block in terms that, rather than being only political or economic, could be described as "legal," with the obvious implication of the "illegality" of any alternative vision in which politics would be hegemonic over professional law. ${ }^{162}$ The emphasis on analogies of the common core approach

158. See Richard Dagger, Democratic Centralism, Encyclopedia Britannica, http:// www.britannica.com/topic/democratic-centralism.

159. See Rudolf B. Schlesinger et al., Comparative Law: Cases, Text, and Materials (5th ed. 1988).

160. Id. (6th ed. 2001).

161. See Schlesinger, supra note 35.

162. See Mattei \& Pes, supra note 141. An attempt to restore some equality of treatment of convergent professionalized systems with other conceptions of law was Mattei, supra note 90. 
provided an intellectual climate favorable to look for convergence or dialogue rather than opposition between common law and civil law. The Cold War generated a need to compare on favorable grounds the West with the rest (where the alternatives to capitalism resisted the U.S. hegemony). The result was an overemphasis on convergence that Schlesinger himself, in his last published piece, denounced as misleading. ${ }^{163}$

\section{The Fall of the Berlin Wall and the Erasure of the Soviet LAW FAMiLY}

At the fall of the Berlin Wall, comparatists did not escape the chorus of self-congratulatory rhetoric that for a decade all but banned critical thinking from Western discourse. ${ }^{164}$ Hans Baade's pages, mentioned above, on the shift from the plan to the market and the complete erasure of socialist law in Koetz's third edition of the Einführung, as well as in Glendon's casebook, ${ }^{165}$ are the best evidence of such an attitude.

Interestingly, the few comparatists still in the business of studying former socialist law deployed the depoliticizing tool par excellence, namely the doctrine of legal transplants, moving it a step forward in the process of explaining legal change with no consideration whatsoever for the social or political context. ${ }^{166}$ Before leaving the field open to the work of scores of corporate practitioners and World Bank advisors, ${ }^{167}$ Gianmaria Ajani, a competent Italian legal Sovietologist, developed the metaphor of import-export of law, while studying competition in U.S. and European legal systems, in order to supply law to Russia and other former Soviet republics or satellites. ${ }^{168}$ This metaphor completed the ongoing global trend to turn law into a technology, something that could be supplied (exported) with no concern whatsoever for the destiny of the import. The former third family of legal systems was thus reduced to a marketplace of legal institutions where the issue was whether it was to be studied from the supply side (competition between exporting countries) or from the demand side. What used to be a field of genuine

163. See Schlesinger, supra note 35.

164. Ugo Mattei, Comparative Law and Critical Legal Studies, in The Oxford Handbook of Comparative LaW, supra note 17.

165. The second edition of Mary-Ann Glendon, Michael W. Gordon, and Christopher Osakwe's Comparative Legal Traditions, appeared in 1994 with all but a complete erasure of Soviet law. In the third edition published in 2007 with Carrozza and Picker, the subtitle Text Material and Cases on Western Law was added.

166. See Watson, supra note 52 and accompanying text.

167. Rose describes this sociological change in Carol Rose, The "New" Law and Development Movement in the Post-Cold War Era: A Vietnam Case Study, 32 LaW \& Soc'y Rev. 93 (1998).

168. See Gianmaria Ajani, By Chance and Prestige: Legal Transplants in Russia and Eastern Europe, 43 Aм. J. Comp. L. 93 (1995). 
research, with a professional group of competent scholars engaged in deep study, became a laboratory of quite superficial observation on the passage "from Marx to markets."169 Thus the "second wave" of law and development, sponsored by the World Bank rather than by the Ford Foundation, inhabited by biased neoliberal economists and legal practitioners, has attracted legal Sovietology into its orbit. Any kind of critique, be it by scholars in self-estrangement ${ }^{170}$ or comparatists interested in understanding a different pattern of law, failed to stave off the assault on the "third family" of legal systems that clearly was no longer needed after the fall of the Wall. ${ }^{171}$ Obviously, this dismissal further proves in retrospect the already discussed Cold War purpose of building it as a family.

Because China had long been expelled from the domain of socialist law (as a "far eastern" legal system in the orientalist vision of Koetz-but why should Germany be the point from where to judge if something is far?), ${ }^{172}$ no comparatist applied to its study any of the previous knowledge on the communist family. Yet, China has maintained a Leninist party structure and a political model of democratic centralism (rule of political law) competing for legal hegemony with traditional conceptions and Western-inspired modernization. ${ }^{173}$ An unbiased legal comparison would therefore engage in a serious study of the post-1978 Chinese Communist Party deploying bourgeois law to accumulate capital, as it happened in the NEP during the 1920s. ${ }^{174}$ Narrow disciplinary political correctness, which has already inserted China into a different family, would not consider that this kind of work the province of comparative lawyers, since the study of parties is the domain of the political scientist and not of the lawyer. China however did not escape the sad fate of becoming the object of business-oriented study based on the import-export metaphor and the assumption that it lacks the rule of law. ${ }^{175}$ Teemu Ruskola, one of the very few legal Sinologists refusing to use self-serving contrastive approaches, has vocally denounced this phenomenon as orientalism. ${ }^{176}$ In spite of the "end" of the Cold War, Western comparative legal rhetoric still needs an "elsewhere," some geopolitical competitor, against which to contrast its own self-image of being the cradle of democracy and the rule of law.

169. See Michael A. Heller, The Tragedy of the Anticommons: Property in the Transition from Marx to Markets, 111 HARv. L. Rev. 621 (1998).

170. See David M. Trubeck \& Marc Galanter, Scholars in Self-Estrangement: Some Reflection on the Crisis in Law and Development Studies in the United States, 1974 WIS. L. REv. 1062.

171. See Rose, supra note 167 , at 122.

172. Id.

173. See Mattei, supra note 90.

174. For some background, see RUSSIA IN THE ERA of NEP: ExPLORATIONS ON SocietY AND Culture (Sheila Fitzpatrick, Alexander Rabinowitch \& Richard Stites eds., 1991).

175. See KRONCKe, supra note 11.

176. See Ruskola, supra note 62. 


\section{The Ideology of the Legal Origins}

If the Cold War climate produced quite a significant improvement in the quality of comparative law, which was at the early taxonomic phase, of functionalism, and of the convergence hypothesis, little of value came from the post-Cold War (end of history) rhetoric. By no means, of course, is this a phenomenon unique to comparative law. The mainstream and the end of history have destroyed dialectic. Intellectual enclosure and self-censorship have all but delegitimized the critique of a mainstream that still celebrates the fall of Soviet Russia as a strategic success.

Historical dialectic generates fruits in terms of civilization and respect. As Quigley has shown in his masterful work, Soviet legal innovation produced genuine "improvement" in many areas of Western law: labor law, criminal law, international law, family law, welfare law, even desegregation in the United States, ${ }^{177}$ have benefited greatly from the presence of a powerful Soviet alternative. The very phenomenon of African decolonization would have been unthinkable in any other but a bipolar world. More generally, the welfare state, whose peak, especially in the United States (L.B. Johnson's "Great Society"), coincided with the peak of Cold War confrontation in Vietnam, cannot be explained outside of it. The above discussion has shown how comparative law has, too, benefited from the Cold War confrontation.

The end of history has produced a fierce capitalist reaction against Cold War-generated legal achievements. There are simply no areas of law where this counter-reformist trend did not emerge. International law returned to secrecy and unilateralism. ${ }^{178}$ Labor law canceled most of the achievements of the workers' movement in the name of flexibility and global competitive needs. ${ }^{179}$ In criminal law, retribution and the certainty of punishment replaced social reintegration. ${ }^{180}$ Even in family law, in spite of increased formal equality, the substantive spaces for emancipation have dramatically declined.

The end of history allowed for the triumph of a variety of neoformalist, economy-driven jurisprudential movements in the United States, replacing legal realism as the dominant mode of thought. ${ }^{181}$ The conservative Olin Foundation in U.S. law schools became the equivalent, fifty years later, of the Rand Corporation, in leveraging "scientific," rational choice games dubbed "law and economics."

177. $I d$.

178. Glenn Greenwald, No Place to Hide: Edward Snowden, the NSA, and the U.S. Surveillance State (2014).

179. Frances Raday, The Decline of Union Power-Structural Inevitability or Policy Choice?, in Labour Law in an Era of Globalization: Transformative Practices and Possibilities (Janne Conaghan, Richard Michael Fischl \& Karl Klare eds., 2002).

180. See Elisabetta Grande, The Rise and Fall of the Rehabilitative Ideal, 2 GLOBAL JURIST TOPICs 1535 (2002).

181. See Mattei, supra note 19. 
In comparative law, the end of history also generated a reactionary phenomenon: the economic literature on "legal origins."182 The genealogy of this move, which culminated in an unprecedented direct involvement of economists in the study of comparative law, is quite clear. To begin with, the comparative mainstream, within its purely scientific claim, started to argue that "measuring" analogies and differences between legal systems was the only legitimate scientific task of our discipline. ${ }^{183}$ Soon after in the early to mid-1990s, some European and U.S. lawyers and economists put together a loose organization, the Comparative Law and Economics Forum, on the implicit assumption that only economics, the queen of social sciences, could provide the intellectual and methodological sophistication necessary to attempt such measurement. ${ }^{184}$ Meanwhile, professional law and economics organizations were established in Latin America, Asia, and elsewhere in Europe. Eventually, a well-connected group of Harvard economists provided the World Bank (already alerted to the existence of comparative law and economics) with materials for a project known as "Lex Mundi," 185 which subsumed the world legal systems divided by their legal origin, civil law and common law. ${ }^{186}$ All the legal systems of the world could then be compared contrastively according to these origins (shared for instance by Italy, the Congo, or Mexico). Different legal origins would explain the comparative efficiency of legal systems measured by a simplified method of statistical regressions based on data such as the number of days necessary to obtain a judgment in commercial matters.

World Bank economists eradicated all the Cold War-induced methodological sophistication that legal comparatists deployed to contrast the Marxist arguments of non-comparability and/or of superiority of the Soviet model: no more taxonomic effort (back to the old Victorian divide across the Channel); no more sophistication in analyzing the sources of law (back to législation comparée); no more convergence hypothesis. Legal origins reduced the triumph of financial capitalism to the triumph of the common law tradition. It

182. See Rafael La Porta, Florencio Lopez-de-Silanes \& Andrei Schleifer, The Economic Consequences of Legal Origins, 46 J. Econ. LiT. 285 (2008) for a survey of a very large body of literature. Cf. Mathias M. Siems, Legal Origins: Reconciling Law \& Finance and Comparative Law, 52 McGiLl L.J. 55 (2007). For a self-reflection within the discipline of comparative law, see Ralf Michaels, Comparative Law by Numbers? Legal Origins Thesis, Doing Business Reports, and the Silence of Traditional Comparative Law, 57 Am. J. Comp. L. 765 (2009).

183. See Sacco, supra note 45.

184. See Mattei, supra note 134.

185. Lex Mundi is self-described as "an exclusive worldwide network of top-tier independent law firms that provides for the exchange of professional information about the local and global practice and development of law; facilitates and disseminates communications among its members; and improves our members' ability to serve the needs of their respective clients." Statement of Purpose, LEx Mund, http:// www.lexmundi.com/lexmundi/Statement_of_Purpose.asp (last visited Oct. 26, 2015).

186. On Lex Mundi, see Schlesinger's Comparative Law, supra note 74, at 267. 
transformed the quest to measure analogies and differences among legal systems into a mere ranking. In this vision, legal systems, like academic institutions, restaurants, or phone companies, can be chosen according to their position in the ranking, where the most powerful and rich are invariably on top, thereby objectifying their assumed superiority and blaming the inferiority on the inferior just like poverty is blamed on the poor by the institutions that sponsor this kind of consumer-based approach. ${ }^{187}$ Interestingly, while during the Cold War, the Bretton Woods institutions respected their explicit mandate not to intervene in the members internal political affairs, the already discussed progressive depoliticization of law (its transformation into an exportable technology) became the Trojan horse for such direct intervention dubbed "law reform." During the Cold War, public institutions (such as the Department of Defense or UN-affiliated organisms such as the World Bank or the International Monetary Fund (IMF)) would not directly finance study (or intelligence) of the law in different countries. They considered it a delicate political matter connected with issues of state sovereignty that required the deployment a variety of private (front) organizations, such as the philanthropic foundations discussed above. ${ }^{188}$ Today there is no more such restraint, which is good news for scholars willing to participate in the construction of dominant rhetoric. The World Bank, the IMF, and many other ideological apparatuses of capitalist hegemony, lavishly fund incursions into the legal systems of the target countries. As Michel Albert has masterfully argued, ${ }^{189}$ capitalism is today itself divided into two fronts, and the city (financial capitalism) fiercely combats production capitalism (the so-called Rhenian model). While the former has its origins in common law, the latter corresponds to the civil law tradition. Hence, predictably the political and economic conditions post-Cold War are ripe for the soft rebirth of the common law versus civil law opposition now in the hands of a new sociological group. ${ }^{190}$

\section{Conclusion}

The literature on legal origins has been the only product of the century-long transformation of comparative law that I have traced that has been known and influential outside a very small group of scholars professionally engaged in comparative law. ${ }^{191}$ While the

187. See Elisabetta Grande, Against The Poor: Homelessness in U.S. Law, 11 GLOBAL JURIST 1934 (2011).

188. See supra Part III.

189. See his classic, Michel Albert, Capitalisme contre capitalisme (1991).

190. See Michaels, supra note 182.

191. The point is made by Michaels, id. See also Mathias Reimann, The Progress and Failure of Comparative Law in the Second Half of the 20th Century, 50 Am. J. CомР. L. 671 (2002). 
Cold War has staged a comparative jurisprudence of intellectual giants, such as Schlesinger, Zweigert, or David, attempting to contrast other intellectual giants, such as Stucka or Pashukanis, its end has produced World Bank-sponsored literature on legal origins: a literature that deploys with no shame the neocolonial narrative of objective Western superiority outside any attempt to dialogue, even within the capitalist block. Unfortunately, as much as our discipline flourished in Cold War conditions, it has declined in the era of globalization and mainstream. Perhaps these are the consequences of our now century-old disciplined incapacity to move beyond the white man's burden. After all, you can indoctrinate students even knowing very little about them. 